\title{
The Photosynthesis of Diatom Cultures in the Sea.
}

\author{
By
}

S. M. Marshall, B.Sc.

Assistant Naturalist,

AND

A. P. Orr, M.A., B.Sc., A.I.C.,

Chemist, Marine Station, Millport.

With 24 Figures in the Text.

Photosynthesis in the open sea is due mainly to two groups of organisms, the diatoms and the dinoflagellates. In British seas the diatoms are so much more numerous that the chemical changes which are due to photosynthetic activity can be almost entirely ascribed to their influence. Recent work on these chemical changes has shown that they do not extend deeper than about 30 metres. Of the external limiting factors light is among the most important and the depth to which photosynthesis can go on must, of course, depend on the light intensity. In the study of the phytoplankton under natural conditions the results are complicated by the interaction of many other factors such as temperature, viscosity, or lack of food salts, so that it is difficult to come to definite conclusions on the effect of light alone.

Early experimental work on the effect of light at different depths was carried out at Monaco by Regnard (1891), who germinated seeds of cress and radish at different depths, and found that little chlorophyll was formed at 30 metres. He also estimated the oxygen production of Ulva over a day, and found that this was too low to measure at 8 and 10 metres. His method, however, was not a delicate one. Jönsson (1903), in the Oslo fjord, using the moss Climacium dendroides, found that photosynthesis fell off rapidly from the surface, and was not appreciable below 17-27 metres. More recently Gaarder and Gran (1927), using samples of sea-water rich in diatoms, found that photosynthesis was considerably less below than at the surface, and that at about 10 metres photosynthesis and respiration just balanced each other. Considering the methods used, and the differences in latitude and season there is probably no real discrepancy in the results of these different observers.

While the results of Gaarder and Gran probably give a true picture of NEW SERIES, - VOL. XV. No. 1. FEBRUAKY, 1928. 
what goes on in the sea in the course of a diatom increase they are still dependent on a combination of factors, and in addition such experimental work is limited to the times when diatoms are sufficiently rich in the sea. By using cultures of diatoms, however, it is possible to control several of these factors and to work at any time throughout the year. The effect of light can then be discussed with greater certainty. The following experiments, carried out chiefly with cultures of diatoms prepared as described by Allen and Nelson (1910), and partly with the diatoms in the sea, had this as their object.

A persistent culture of Coscinosira polychorda was used. A " persistent culture" was defined by Allen and Nelson as a culture in which only one species of diatom was present, although there might be bacteria and a small number of other organisms such as flagellates. In our cultures there were always bacteria, and in old cultures minute flagellates were sometimes seen. Coscinosira is not noted as occurring commonly here or in the North Sea, but it is very similar to species of Thalassiosira, and may have been counted along with them by mistake. Gran (1912) states that its occurrence agrees with that of $T$. nordenskioldi, but says it may have been confused with Thalassiosira sp. It has its maximum in March. The number of cells per c.c. of culture was estimated for each experiment, so that the results could be expressed as the amount of oxygen produced by a million diatoms. A young culture will, however, produce more oxygen per million cells than an old one, and even two cultures of the same age grown under the same conditions do not always behave exactly alike, so that the actual amounts of oxygen in different experiments may not be strictly comparable. As far as possible cultures of about the same age and cell content were used in these experiments.

Considering the importance of light for photosynthesis it would have been desirable to estimate its intensity in conjunction with the experiments. There is as yet, unfortunately, no suitable method for the continuous measurement of light intensity at different depths in the sea. Of several methods tried, the recent one of Anderson and Robinson (1925) was found suitable for continuous measurement of the intensity in the air, but not for measurements below the surface. This method depends on the decomposition of oxalic acid in the presence of traces of a uranium salt when exposed to light and measures the intensity of wave-lengths shorter than 4,500 $\AA$, although even then absorption by the solution is only partial. The amount of absorption increases as the extreme violet end of the spectrum is approached. There are two objections to the use of the method in the sea. As decomposition goes on, gases are evolved, causing an increase in pressure which inhibits the reaction and in addition there is superimposed the pressure of the column of sea-water overlying the tube. In the second place absorption of light of very short wave- 
length by sea-water is rapid and the results obtained below the surface are low. The wave-lengths measured are not those generally thought to be responsible for photosynthesis. By this method, in default of a better one, results are obtained in air which are of use in comparison with photosynthesis. Some of them are shown in conjunction with later experiments.

Photosynthesis was measured by the oxygen production as estimated by Winkler's method. This is a very reliable method in most cases, but when the solution was highly supersaturated small bubbles were often formed and duplicate samples did not then agree well. As a rule, short experiments gave more accurate results. No special precautions were

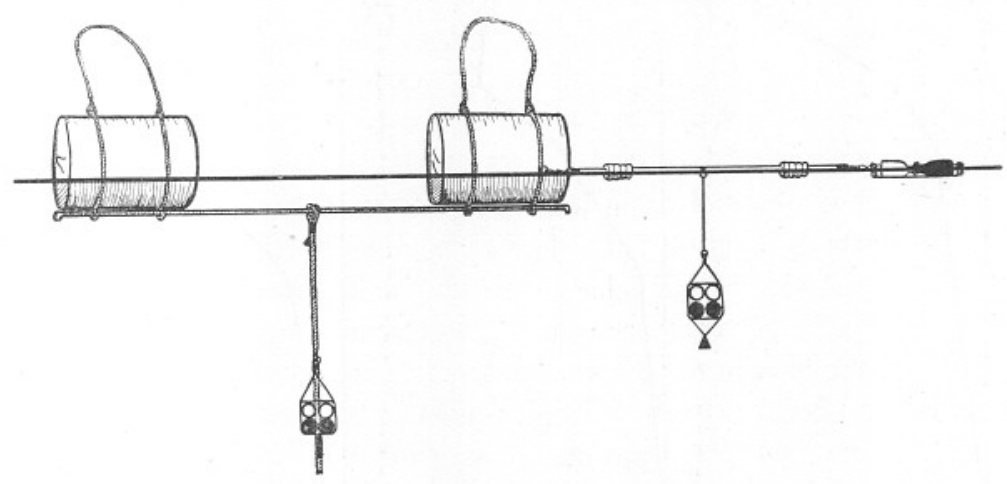

Frg. 1.-Arrangement of apparatus in the sea.

taken to keep the bottles at the same temperature until they were titrated, and according to Ruud (1926) this decreases the accuracy of the method.

The diatom culture was enclosed in ordinary white glass reagent bottles of about 150 c.c. capacity with well-ground stoppers, and these were arranged in cages of wide-mesh wire-netting, so that the long axes of the bottles lay horizontally. A buoy (Fig. 1) was anchored in the position chosen, and the cages were then hooked on to the buoy rope at various depths, a heavy weight being attached below the bottom cage to keep the rope vertical. For the surface bottles a small float was made which was attached to the end of a stick, the other end of which was hooked on to the buoy, and from this stick the half-metre cage was also suspended to avoid the buoy's shadow. To reduce shadow effects the buoy used was double, two drums being connected by a rigid bar to the middle of which the rope was attached. In each cage there were two bottles in the light (these being uppermost), and one bottle painted black and enclosed in a dark cloth bag. The presence of the dark cloth prevented the reflection of any light from below. The oxygen produced in the two lighted bottles measured photosynthesis minus respiration, while 
the fall in oxygen content of the dark bottles measured respiration alone. By adding this oxygen loss to the oxygen production in the light bottles, the total photosynthesis could be calculated. It was found that the results from all the dark bottles in an experiment were very nearly the same, and any differences showed no relation to increasing depth or temperature. The average was therefore used in calculating photosynthesis. The experiments were carried out as far as possible while the sea was free from diatoms. Greenwich Mean Time is used throughout.

The early experiments (Figs. 2, 3, 4, and Tables I, II, III, on p. 343) were carried out in March, 1927, in Loch Striven, ${ }^{*}$ and the photosynthesis

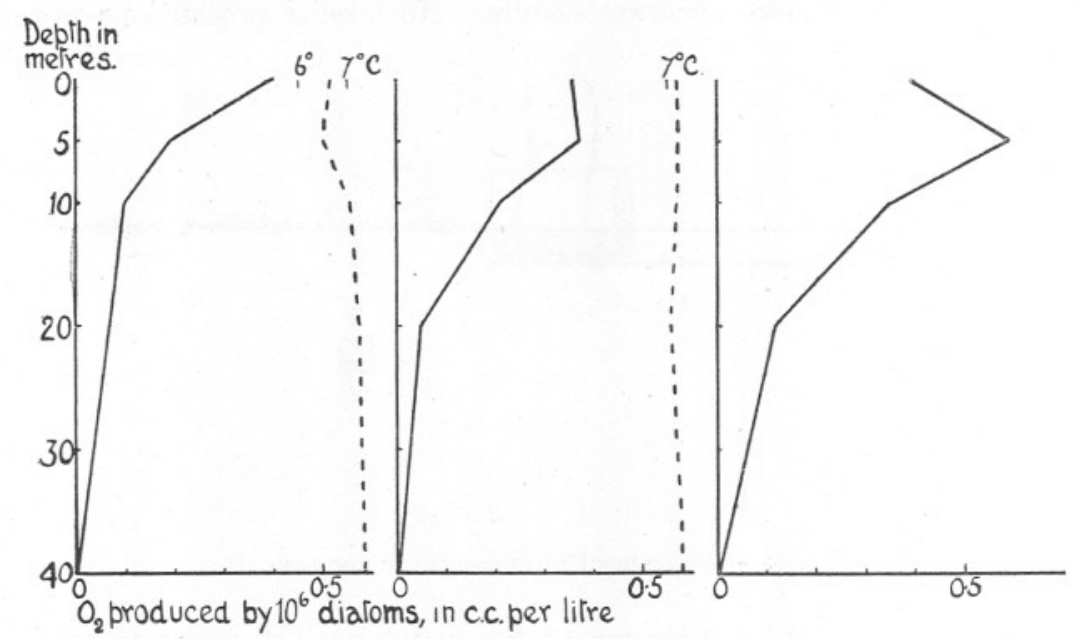

Fig. 2.-Oxygen production Fig. 3.-Oxygen production per $10^{6}$ diatoms in Loch per $10^{6}$ diatoms in Loch Striven. $18-19 / 3 / 27$. Striven. 28-29/3/27.

Frg. 4.-Oxygen production per $10^{6}$ diatoms in Loch Striven. $31 / 3-1 / 4 / 27$. - oxygen production; . . . . temperature.

over 24 hours measured at depths of $0,5,10,20$, and 40 metres. Fig. 2 shows graphically the oxygen produced by a million diatoms at these depths on March 18th-19th. The sky was overcast and there was no sunshine. Sea temperature was low throughout, about $7^{\circ} \mathrm{C}$. with a slight fall to the surface. Photosynthesis showed a marked maximum at the surface decreasing rapidly in deeper water. At 5 metres the difference in oxygen content between the original culture and the lighted bottles fell within experimental error, i.e. the amount of oxygen produced by photosynthesis was just equal to the amount of oxygen used up by respiration. The light intensity at which this occurs is called the compensation point. Below this photosynthesis may still go on, but there is a continuous loss of oxygen and life becomes impossible.

* On old charts this is spelled Strivan, but the current use is Striven. 
Fig. 3 shows the type of curve obtained during brighter weather about the same date, March 28th-29th. There were 5 hours 50 minutes sunshine during this experiment. The temperature was not taken on this occasion, but the curve for March 26th is given and this is not likely to have altered much. The loch was homothermic, about $7^{\circ} \mathrm{C}$. The most interesting features of the photosynthesis curve are that the compensation point is much deeper, 10-20 metres, and that photosynthesis instead of rising all the way to the surface has stopped increasing above 5 metres. It is possible that in the brighter weather of this experiment, temperature and not light was the limiting factor above 5 metres, i.e. the vertical part of the curve represents the maximum amount of photosynthesis possible at that particular temperature. Fig. 4, however, shows that another explanation is more probable. This experiment was carried out on March 31st-April 1st, when there were 5 hours 15 minutes sunshine. The compensation point is still between 10 and 20 metres, but as can be seen from the curves the production at 10 metres is considerably greater than in the previous experiment. Above 5 metres there is a sharp fall in oxygen production, a fall which cannot be accounted for by temperature, and which must be due to the strong light at the surface. The fact that there was almost the same amount of sunshine during these two experiments makes the difference between them surprising, but as will be seen later not only sunshine, but also bright diffuse light can be supraoptimal for diatom photosynthesis. The weather was brighter during this experiment than during the previous one, and this is probably the cause of the difference between the two curves. With one exception other experiments done about the same time showed similar results, an increase to the surface on dull days and a decrease on sunny days. The exception was on April 5th-6th in rather dull weather with numerous intervals of sunshine amounting altogether to 8 hours 35 minutes. On this day oxygen production rose steadily all the way to the surface, reaching a high value there.

In the middle of March when the spring diatom increase was at its height, very low values were obtained for depths below the surface, the compensation point lying between the surface and 5 metres. The weather was dull, but it is certain that a good deal of light was cut off by the enormous number of diatoms suspended in the water.

When diatoms are exposed to too strong illumination the chromatophores contract and collect in the middle or at one side of the cell. This condition of "systrophe" was described by Schimper (Karsten, 1905), who supposed that the light optimum for most species lay below the surface and for the main bulk of diatoms at a depth of 40-60 metres. Whipple (1914) found by experiment that photosynthesis was more active at a depth of 6 inches than at the surface, because of the strong 
light there. Ruttner (1926) carried out a number of experiments in the Lunzer See on photosynthesis in Elodea and other fresh-water plants, and found that in sunny weather the light became too strong at the surface and photosynthesis decreased there. Gran (1927) also mentions the injurious effect of strong light on diatoms, and considers that at a depth of 5 metres the diatoms are under optimal conditions. In several experiments we exposed samples at a depth of $18 \mathrm{~cm}$., and the harmful effect was still noticed but to a much less degree than at the surface, indicating that the part of the spectrum responsible for this adverse effect is rapidly absorbed.

Light of short wave-length has been shown to have a harmful effect on the growth of land plants, and since the violet part of the spectrum

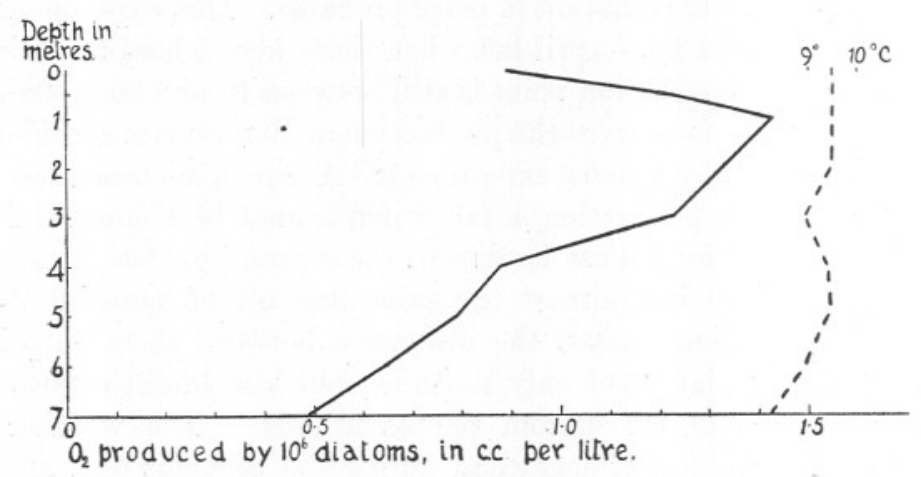

Fig. 5.-Oxygen production per $10^{6}$ diatoms in Loch Striven, 18-19/5/27. ... Temperature.

is rapidly absorbed by sea-water it seemed possible that this might account for the decreased amount of photosynthesis at the surface. Ordinary glass absorbs this short wave-length light, but Uviol glass (made by Schott and Co., Jena) allows it to pass. Several comparisons were, therefore, made with bottles of the two types of glass at different depths in the sea. Except in one sample, however, the differences between them were within experimental error.

Several experiments were then carried out with cages at $0, \frac{1}{2}, 1,2,3$, $4,5,6$, and 7 metres to find the position of optimal light intensity. The result of one such experiment is shown in Fig. 5 and Table IV. Here the maximum is at 1 metre with a rapid fall both above and below this depth. On this day there were 5 hours 55 minutes sunshine. On another day with 5 hours 5 minutes sunshine, a similar experiment showed the maximum at half a metre.

As summer approaches photosynthesis goes deeper. Fig. 6 and Table V give the results of an experiment down to 60 metres on a sunny day near 
midsummer. Unfortunately the surface and half-metre samples were lost, and so the fall in photosynthesis to the surface is not shown. There is a rapid and fairly regular fall from 1 metre down to 20 metres when the decrease slows off. The compensation point lies between 20 and 30 metres. This curve also brings out clearly the much greater amount of photosynthesis possible in the sea during the long summer days than in the short days of early spring.

Since the optimal depth depends so closely on the light intensity, its

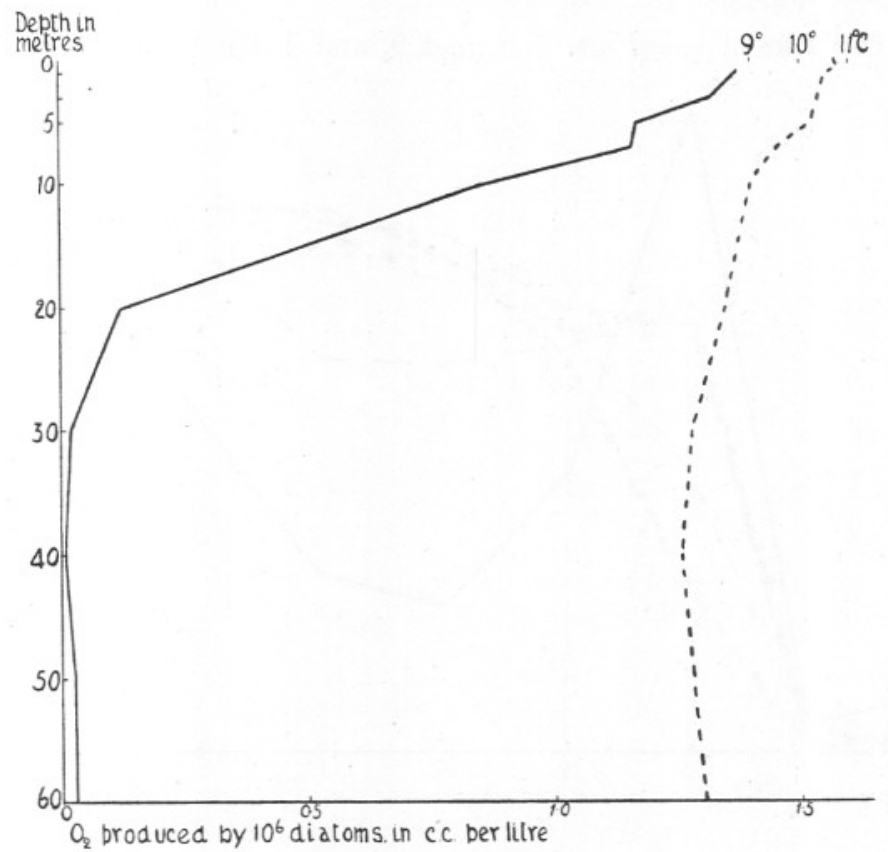

Fig. 6.-Oxygen production per $10^{6}$ diatoms in Loch Striven. 13-14/6/27. . . . Temperature.

position must vary during the course of the day. McLean (1920) and Yap (1920) have shown that the rate of photosynthesis of sugar-cane in the Philippines increases rapidly from about 7.30 a.m. to 9.30 a.m. and falls slightly in the middle of the day, rising again to a maximum about 5 p.m. An experiment was carried out to find the actual course of photosynthesis in the sea on a sunny day. Cages were sunk to $0, \frac{1}{2}, 1,2$, 3,4 , and 6 metres, and were changed every 3 hours over 24 hours. The diatom culture used (about 30 litres) was the same throughout, and the number of cells counted at the beginning and end of the experiment. It did not increase, probably because the culture was old enough for its rate of increase to have fallen to a figure within the limit of error of the 
counting method $(10 \%)$. It will be noticed that the initial samples do not agree closely, and this is probably due to inefficient mixing. Mechanical stirring was carried on 15 minutes before as well as during the filling of the bottles, one initial sample being drawn off first, the other after filling the experimental bottles. In a subsequent experiment where mixing went on during the whole 24 hours duplicates agreed more closely. This, however, does not affect the final results at all. The buoy was anchored in about 9 metres off Farland Point, a few minutes distant from the Marine Station.

The experiment (see Figs. 7, 8, and 9, and Table VI) was carried out

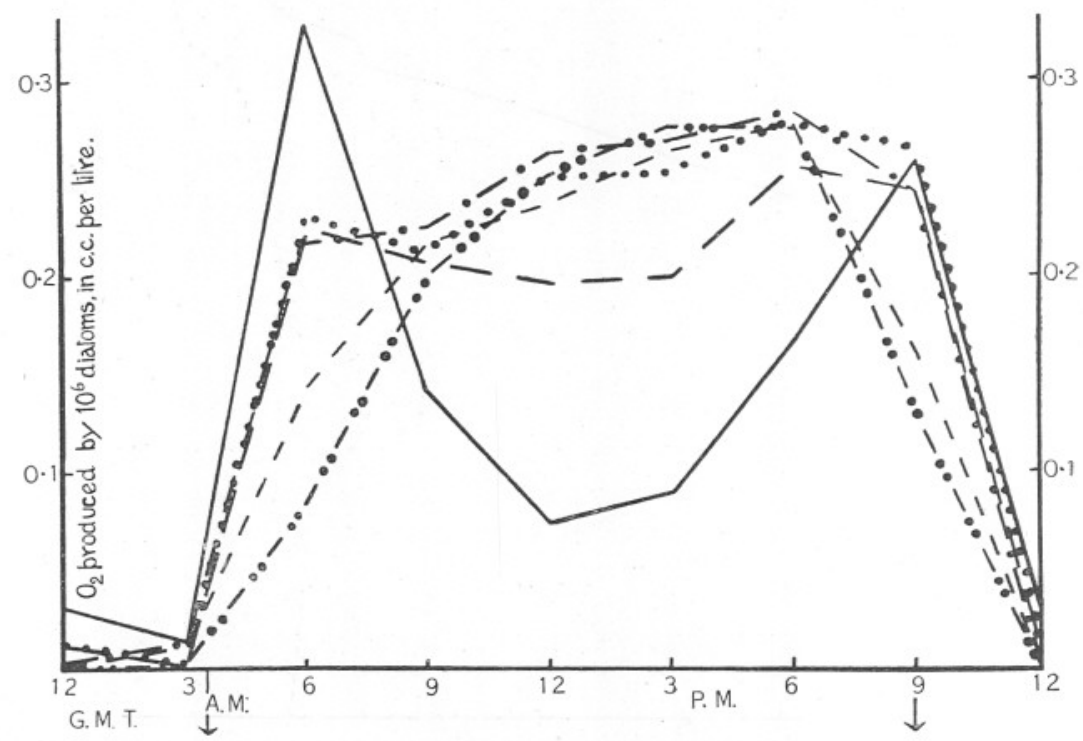

FIG. 7.-Photosynthesis over 3-hour intervals during a sunny summer day. 15 hours 5 minutes sunshine. June 9-10. Sun's meridian altitude, $57^{\circ} 10^{\prime}$.

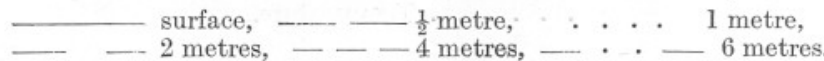

near midsummer and a bright day chosen. The length of the day was 17 hours 22 minutes (sunset and sunrise are marked on the figure by arrows), and there were 15 hours 5 minutes sunshine during the experiment. The light was also measured by Anderson and Robinson's method and from the half-hourly readings the curve (Fig. 13) constructed. The experiment was begun at 6 a.m. on June 9 th, and carried on till 6 a.m.. June 10th, but for convenience the curves are drawn as from 12 midnight. The mornings were equally calm and cloudless, and there is probably no error involved in doing this. It was scarcely dark all night, the darkest hours being from midnight till 3 a.m. During these hours the 
oxygen production at all depths was negligible. From 3-6 a.m. the surface curve reaches its maximum and the maximum production for any depth during the day. This was followed by a rapid fall from 6-9 a.m. and a further fall from 9 a.m. till 12 noon. After this there was a slight but gradual increase till 9 p.m. where the curve shows another peak, though not so high as the morning one. Photosynthesis then fell rapidly because of lack of light. From 9 p.m. till 12 midnight there was still a slight production of oxygen, but only at the surface. The half-metre samples.

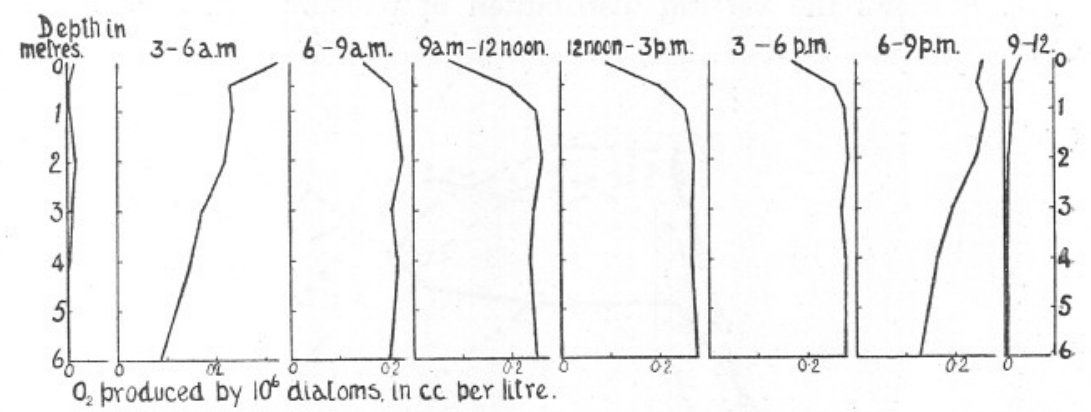

FIG. 8.-Vertical curves showing photosynthesis every 3 hours (June 9-10).

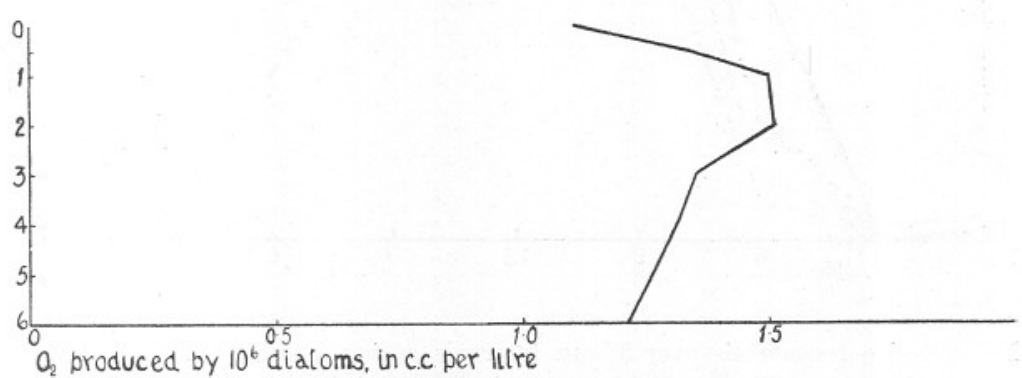

FIG. 9.-Composite curve showing total photosynthesis from the above curves (in Fig. 8).

show a similar curve, with the morning and evening peaks flattened off and the midday depression less marked. The curves for the other depths are very like each other from 9 a.m. till 6 p.m., showing a gradual rise to a maximum at 6 p.m. Before 9 a.m. and after 6 p.m. the curves for the layers below the surface separate from one another, the 4- and 6 -metre curves falling off more rapidly than the others. It should be noticed that no curve follows that for light intensity shown in Fig. 13.

This decrease in photosynthesis in deeper water may be due partly to the total reflection of the sun's rays in the morning and evening and partly to the diffuse light being sub-optimal below the surface. The loss of light by reflection even in summer is variable, depending on the height 
of the sun, the clouds, and the surface of the sea. Poole and Atkins (1926) have found reflection to vary from 5-31\%. With fresh water, according to Schmidt (quoted by Ruttner, 1926), reflection is from 0-6\% when the angle of incidence is from $0-60^{\circ}$, is $13 \%$ at $70^{\circ}, 35 \%$ at $80^{\circ}$, and $100 \%$ at $90^{\circ}$. The variation in reflection between midday in summer and midday in winter is $12 \%$. This is for the direct rays of the sun, while of diffuse light about $17 \%$ is reflected. These figures vary, of course, with the latitude, and from day to day with the weather.

Fig. 8 shows the vertical distribution of photosynthesis over each

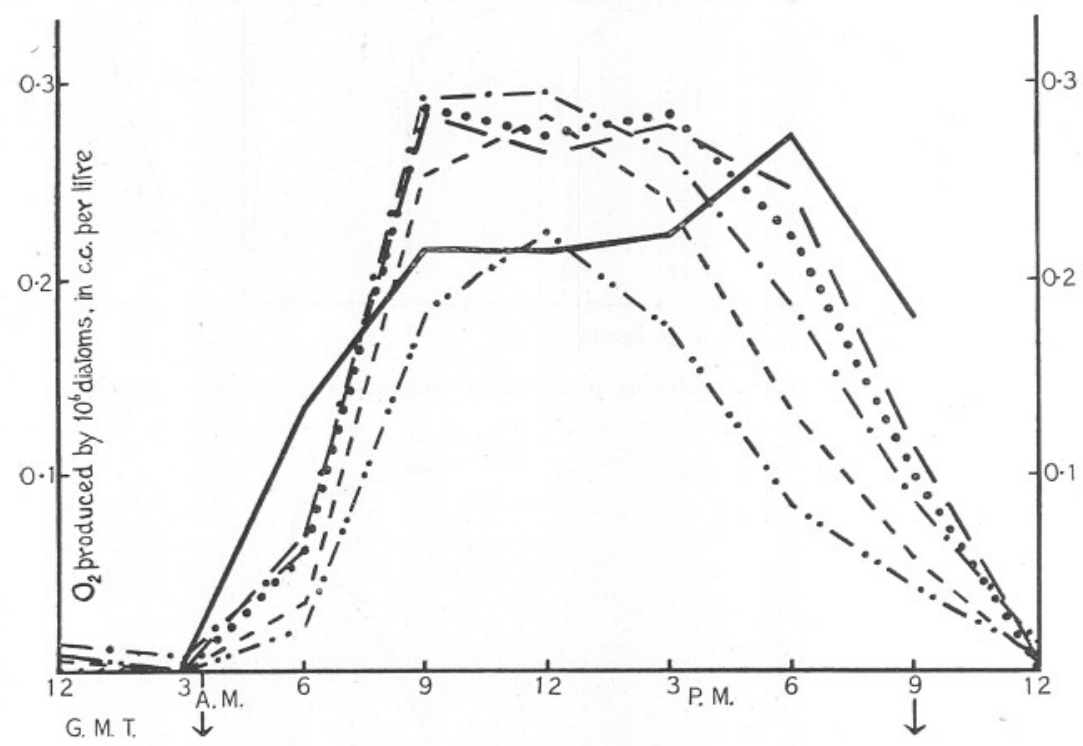

FIG. 10.-Photosynthesis over 3-hour intervals during a dull summer day. No sunshine. June 28 . Sun's meridian altitude, $57^{\circ} 34^{\prime}$.

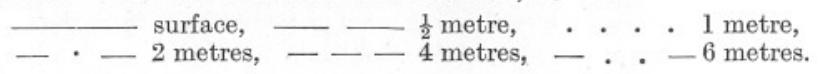

3-hour period, and Fig. 9 the curve obtained by adding the separate values for each depth together. The latter can be compared with the all-day curves. The maximum over the day is at 1 or 2 metres, the fall above and below these depths being rapid. This curve can only be an approximation to the truth, because the values for each three hours are those given by a fresh uninjured diatom culture, and not by diatoms which have remained all day in the strong light. That recovery can take place was shown by an experiment carried out over 48 hours on land in which the bottles were all put outside at the beginning and two taken in each three hours. Although the bottles were exposed only to strong diffuse light the resulting curve showed a deep midday depression and 
a morning and evening peak. On the other hand, experiments have shown that whereas in sub-optimal light it is possible to add the results of two successive 3-hour exposures together and obtain the same result as for a 6 -hour exposure, in strong light this cannot be done. The stronger the light the more marked is the injury. In one case where a culture cooled by running water was exposed to the direct sun all day, the majority of the diatoms were killed and the culture showed only a slight recovery

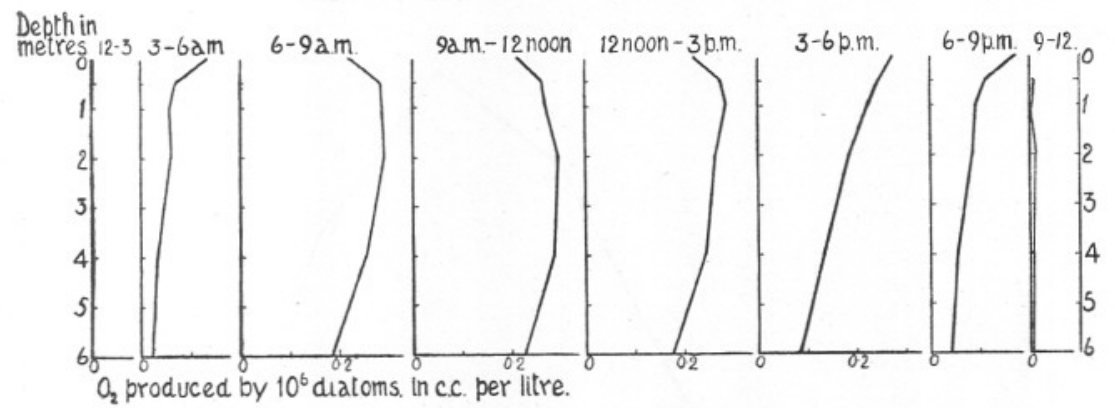

Fig. 11.-Vertical curves showing photosynthesis every 3 hours (June 28).

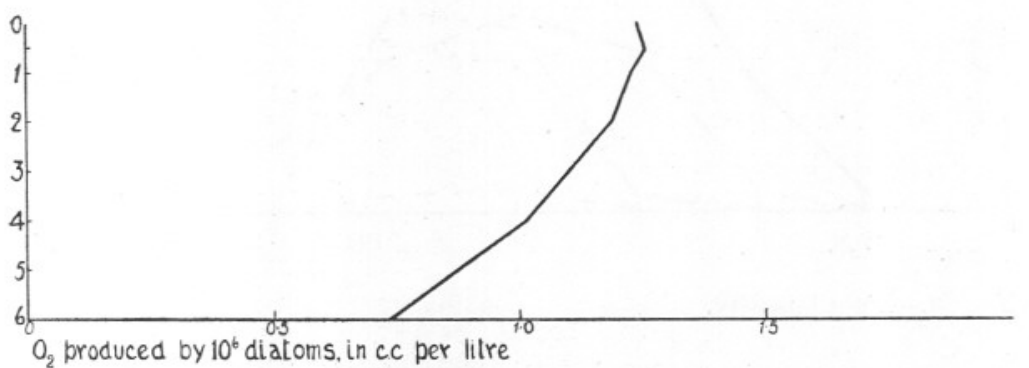

Fig. 12.-Composite curve showing total photosynthesis from the above curves.

after 6 days. From this it is clear that the greatest amount of photosynthesis at or near the surface takes place in the early morning in sunny weather.

It was felt that a comparison of this experiment with a similar one carried out on a dull day would provide interesting results. For this only the $0, \frac{1}{2}, 1,2,4$, and 6 metres were worked. The experiment was started at midnight, June 27 th-28th, and continued for 24 hours. The day was 17 hours 30 minutes long and there was no sunshine. The sky was heavily overcast most of the day, but there was no rain till the evening of the 28th. The results are shown in Figs. 10, 11, 12, and 13 and Tables VII and XIII. When we compare the curves in Fig. 10 with those for the previous experiment striking difference sre aseen. The surface curve 
shows no morning peak, but photosynthesis rises gradually from 3-6 a.m. and from 6-9 a.m., when it remains almost constant till a rise to the evening maximum at 6 p.m., not 9 p.m. as before. After this the curve falls sharply. Unfortunately the surface samples for 9 p.m.-12 midnight. were lost because of rough weather, but it is certain that the curve would have fallen to a low value. The $\frac{1}{2}-, 1-$, and 2 -metre curves again resemble one another, the $\frac{1}{2}$ and 1 metre each showing a slight midday depression. The 4- and 6-metre and to a less extent the 2 -metre curves are symmetrical,

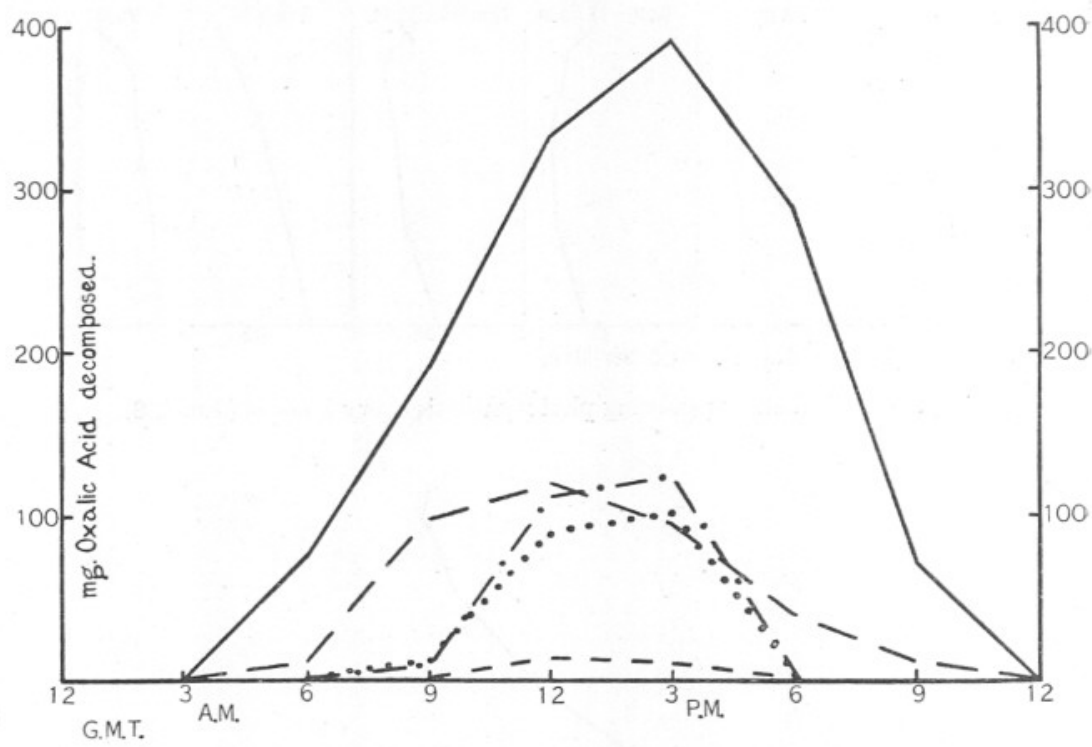

FIG. 13.-Light intensity.

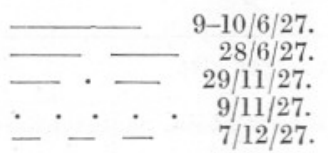

rising steadily to a maximum at midday and falling off thereafter. If we compare them with Fig. 13 we see that the 4- and 6-metre curves agree precisely with the light curve for the day. The inhibitory effect of the high light intensity had disappeared somewhere between 2 and 4 metres on the dull day, whereas it affected every depth investigated on the sunny day. Photosynthesis began later and fell off earlier, and the maximal values are found from 9 a.m. till 3 p.m. The vertical curves (Fig. 11) show this clearly, but although the composite curve shows that the total amount of photosynthesis was greater even at $\frac{1}{2}$ metre on the sunny than on the dull day, it is not safe, as has already been mentioned, to conclude that this was really the case. The curves in the morning and evening are further apart than they were on the sunny day. These two 
experiments show that the curves for earlier experiments can be analysed, so as to bring out the effect of a number of separate factors. The steep fall in photosynthesis in deeper layers is due largely to the morning and evening fall-off in intensity as well as to the sub-optimal light, while the surface fall is a cumulative effect over the brighter part of the day.

Similar experiments were carried out in winter in sunny, bright, and dull weather. The results of these are shown in Figs. 14-22 and Tables VIII, IX, X, and XIII. The results obtained on a sunny day (Nov. 29th)

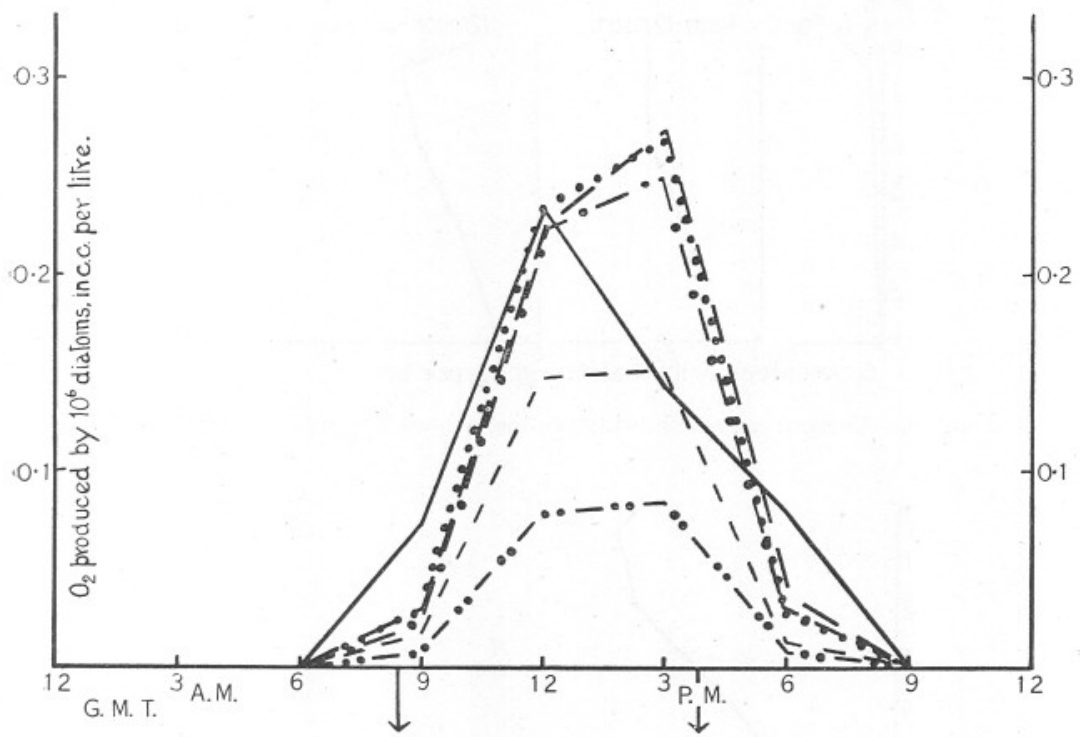

FIG. 14.-Photosynthesis over 3-hour intervals during a sunny winter day. 6 hours sunshine. November 29 . Sun's meridian altitude, $12^{\circ} 53^{\prime}$.

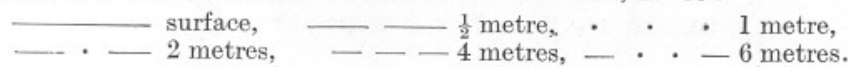

are shown in Figs. 14, 15, and 16 and Table VIII. The day was 7 hours 25 minutes long, and the sun shone all the time, although only 6 hours were recorded. The Secchi disc reading was $7 \frac{3}{4}$ metres, but this low reading is probably due to the turbidity following a S.W. wind the previous day. It was quite dark before 6 a.m. and after 6 p.m. Values were low at all depths from 6 a.m. to 9 a.m., but by noon had risen rapidly and the surface had reached its maximum for the day, the surface $\frac{1}{2}, 1$, and 2 metres having almost the same values. The 4 - and 6 -metre layers were much lower. By 3 p.m. the surface layer had fallen considerably, owing to the strong sunlight while there was a further rise at $\frac{1}{2}, 1$, and 2 metres. The 4- and 6-metre layers showed little change. By 6 p.m. photosynthesis had fallen to a low value everywhere except at 
the surface, and by 9 p.m. it had stopped completely. The light curve for the day (see Fig. 13 and Table XIII) agrees well with the depths below the surface, while the greatest injury at the surface coincides with the peak of the light curve.

In Figs. 17, 18, and 19 and Table IX are shown the results obtained on a bright day in winter. The day was 8 hours 38 minutes long, and there were 2 hours 55 minutes sunshine recorded. The day was bright,

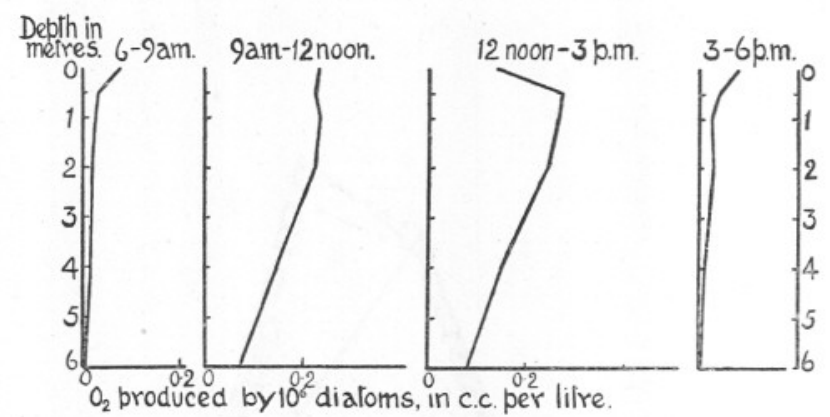

FIG. 15.-Vertical curves showing photosynthesis every 3 hours (Nov. 29).

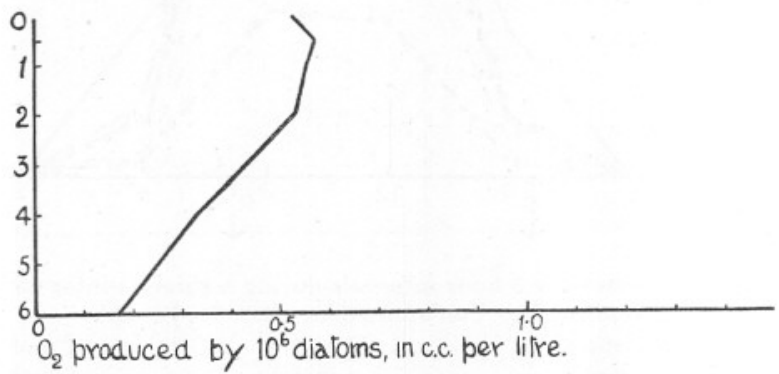

FIG. 16.-Composite curve showing total photosynthesis from the above curves.

but there were rapidly moving high clouds which frequently obscured the sun. The experiment took place on November 9th, and is very similar to the last in results. Between 12 noon and 3 p.m. there were 2 hours of uninterrupted sunshine, which accounts for the injury at the surface shown then. There is a greater separation of the curves for the layers below the surface on this day than on the sunny day. This is due, no doubt, to the lower light intensity on this day as well as to the visibly greater turbidity of the water. Unfortunately no Secchi disc reading was taken. Figs. 16 and 19 are the composite curves for these two experiments. In each case the maximum is at $\frac{1}{2}$ metre and the curves fall off steeply in deeper water. 
The dull day chosen, December 7th, is represented in Figs. 20, 21, and 22 and Table $\mathrm{X}$. The sky was quite overcast, and there was a certain amount of low-lying fog. The day was 7 hours 7 minutes long and there was no sunshine. The Secchi disc reading was $8 \frac{1}{2}$ metres. The light intensity for the day is shown in Fig. 13 and Table XIII, and is extremely low. Light on this day never reached an optimal value at the surface, and there is a regular fall in photosynthesis from depth to depth throughout the day. The respiration over a 3-hour period is too low for experimental error to be negligible, so to find the depth of the compensation

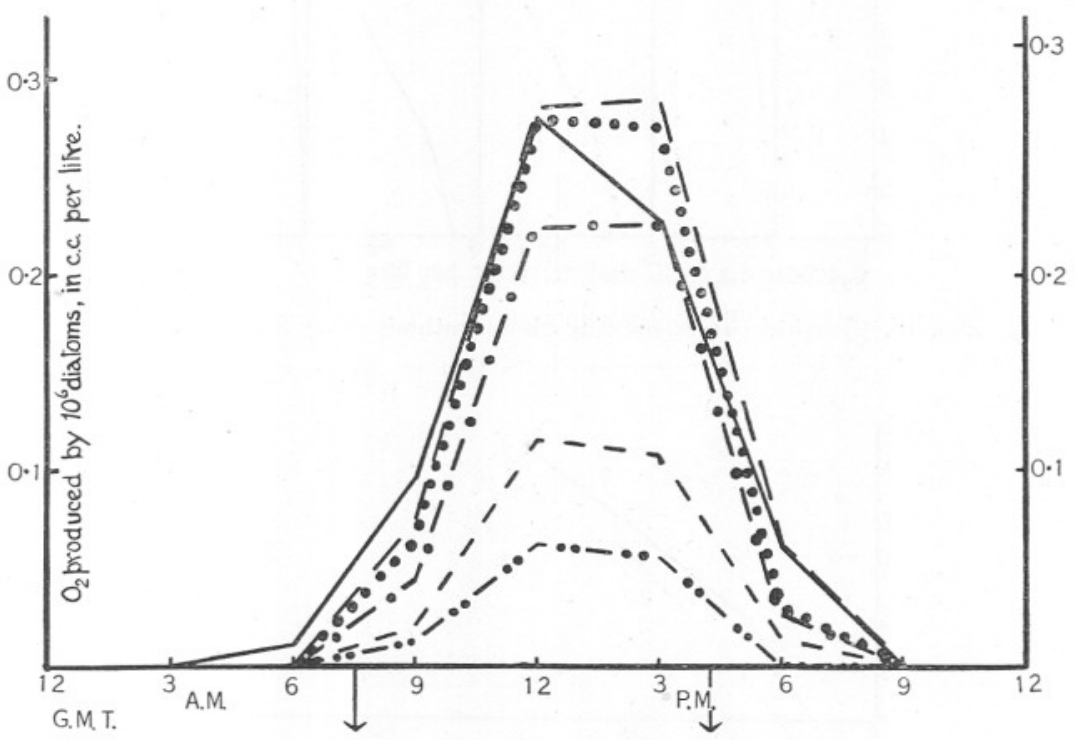

Fig. 17.-Photosynthesis over 3-hour intervals during a bright winter day. 2 hours 55 minutes sunshine. November 9 . Sun's meridian altitude, $17^{\circ} 35^{\prime}$.

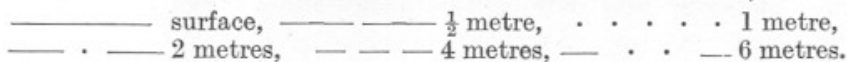

point samples were kept in the dark for 24 hours. The compensation point lay between 4 and 6 metres. On a very foggy day (Nov. 30thDec. 1st) an experiment in the sea showed the compensation point to be at about 2 metres, which is the least depth we have found.

In comparison with the summer curves the most striking difference is the short time available for photosynthesis. There is also a much more rapid falling off with depth which agrees with the lower curves for light, and is probably due in part to the greater obliquity of the sun's rays and possibly also to the greater turbidity of the sea in winter. The amount of photosynthesis taking place at the surface and $\frac{1}{2}$ metre in the middle hours of the day is not very different from what takes place in 
summer. As might be expected the winter sun has less effect than the summer sun, and injury does not appear to extend much beyond the surface layer.

It may be suggested that the inhibitory effect of strong light was not caused by the light itself, but by the increasing temperature which accompanies sunlight. At the time of the summer experiments showing

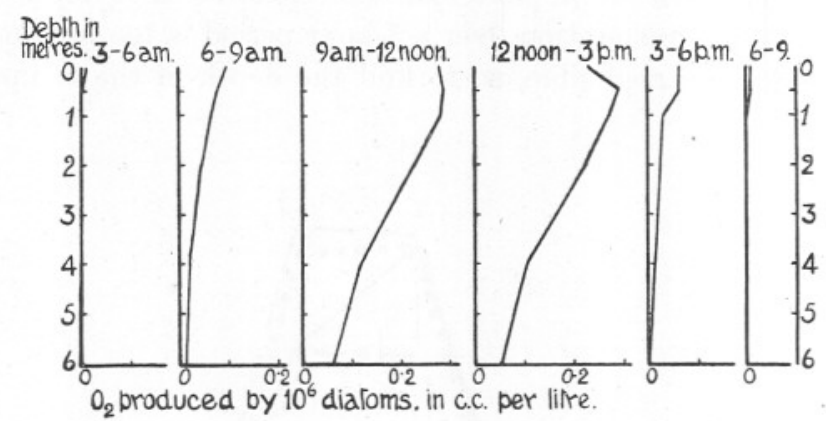

FIG. 18.-Vertical curves showing photosynthesis every 3 hours (Nov. 9).

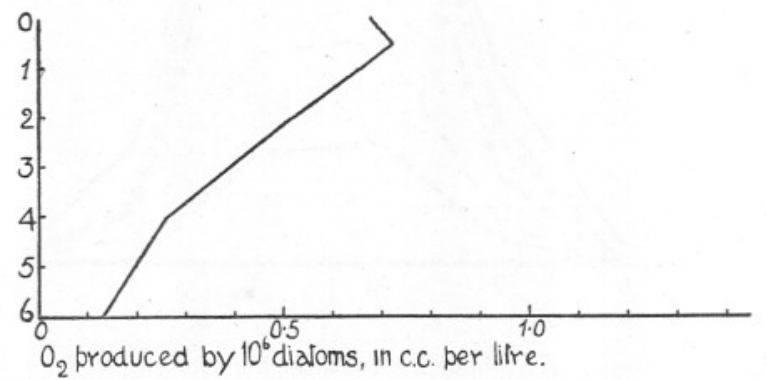

Fig. 19.-Composite curve showing total photosynthesis from the above curves.

diurnal variation, the surface temperature was about $12^{\circ} \mathrm{C}$., and there was probably a difference of several degrees between the surface and 6-metre layers, although the diurnal variation would be small. During the winter experiments the temperature was about $10^{\circ} \mathrm{C}$. Experiments in the laboratory have shown that an increase of temperature up to $15^{\circ} \mathrm{C}$. does not injure the diatoms, although a temperature of $25^{\circ} \mathrm{C}$. does. The temperature therefore cannot be the cause of the diurnal variations in photosynthesis. As has already been mentioned, respiration figures showed no significant variation at different depths.

It seemed possible that different species of diatoms would show a different relation to light of varying intensity since some are characteristically summer forms and others winter or spring forms. Fig. 23 and 
Table XI show a comparison of photosynthesis in cultures of Coscinosira and Chætoceros (probably C. cinctum) over 24 hours in bright weather. The Chætoceros species used has much smaller cells than Coscinosira, so the amount of oxygen produced by a million cells of each is not comparable and the total oxygen produced is shown as well. The unexpected result is obtained that Chætoceros, which is here a summer form, is much more sensitive to light than the spring diatom Coscinosira. In the surface layer Chætoceros lost oxygen instead of producing it, and photosynthesis

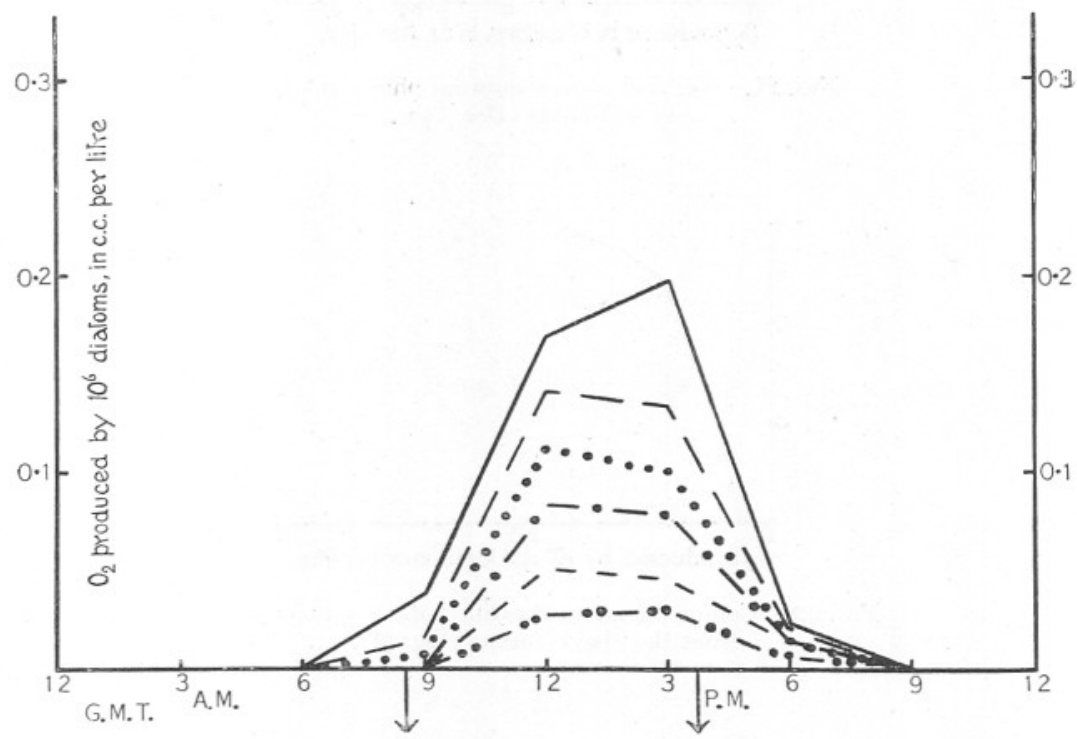

FIG. 20.-Photosynthesis over 3-hour intervals during a dull winter day. No sunshine. December 7 th. Sun's meridian altitude, $11^{\circ} 42^{\prime}$.

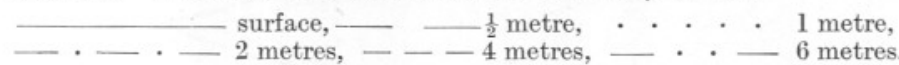

remained almost the same from 1-4 metres. This experiment gave similar results on the three separate occasions on which it was tried. A curious irregularity is shown in the photosynthesis curve at 4 metres, particularly with Coscinosira. Such irregularities, sometimes even more marked, appeared occasionally for no obvious reason. It is interesting to note that on July 18th, when diatoms were rich in the sea (mainly Chatoceros cinctum, Skeletonema costatum, and Thalassiosira gravida), the percentage showing systrophe at the surface was as follows: $C$. cinctum, $33 \%$; S. costatum, $8 \%$; T. gravida, $0 \%$.

The cultures were grown in a north window and were never exposed to full daylight. It therefore seemed possible that the inhibitory effect of strong light might be due to this fact alone (i.e. growth in weak light),

NEW series. - vol. Xv. No. 1. FebrUARY, 1928. 


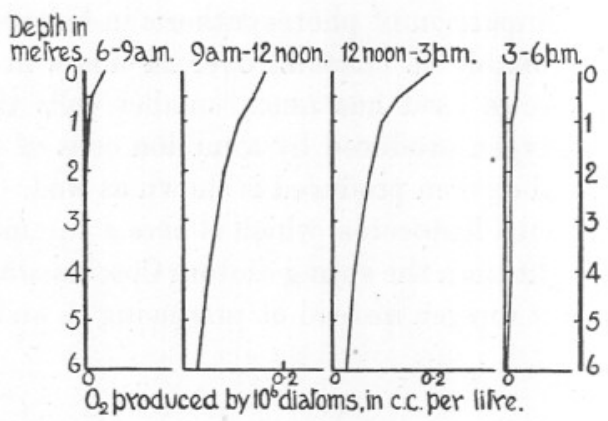

Frg. 21.--Vertical curves showing photosynthesis every 3 hours (Dec. 7 th).

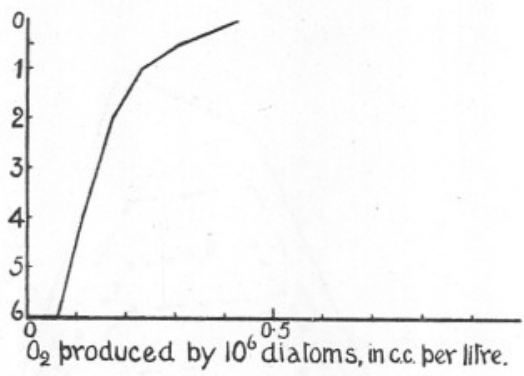

FIG. 22.-Composite curve showing total photosynthesis from the above curves (Fig. 21).

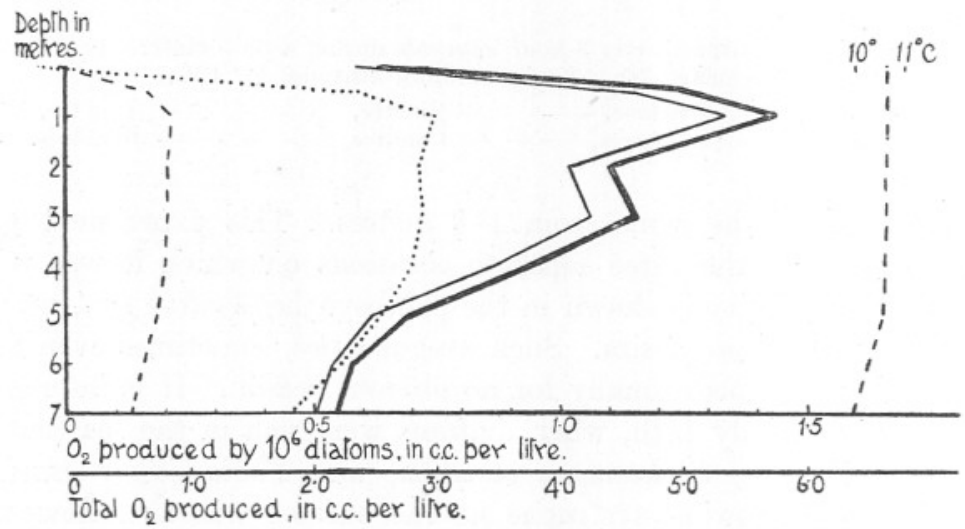

FIG. 23.-Comparison of different species of diatoms. Loch Striven. 27-28/5/27.

Coscinosira. Total oxygen produced.

Oxygen produced per $10^{6}$ diatoms.

Chætoceros. Total oxygen produced. . . . . . .

Oxygen produced per $10^{6}$ diatoms. -- 
and that the results were not applicable to diatoms in the sea. In March, during the spring diatom increase, samples of sea-water were sunk at various depths along with diatom culture. The oxygen production was usually lower than that of the culture, and was generally low except at the surface and occasionally at 5 metres. It is possible that these results are complicated by a lack of nutrient

salts. By March 27th diatoms had almost disappeared and these experiments were discontinued. In July, however, a diatom increase (referred to above) began, and samples of the rich surface water were used for an experiment on July 18th. Fig. 24 and Table XII show the results for a sunny 5-hour period in the middle of the day down to 15 metres. The general shape of the curve is the same as those for culture experiments. At the surface and $\frac{1}{2}$ metre the sunlight was injurious, while below 2 metres there was a gradual falling away. This makes it clear that strong light has an inhibitory effect on diatoms grown under natural conditions as well as on those grown artificially.

When we compare the results of the experiments recorded above with the observations available on the vertical distribution of diatoms in the sea we find considerable disagreement. Phytoplankton has been found as deep as 1000 metres, and "maxima" have been recorded from depths ranging from the surface to 70 or 80 metres. Lohmann (1908) first described how after a diatom increase the cells sank gradually to the

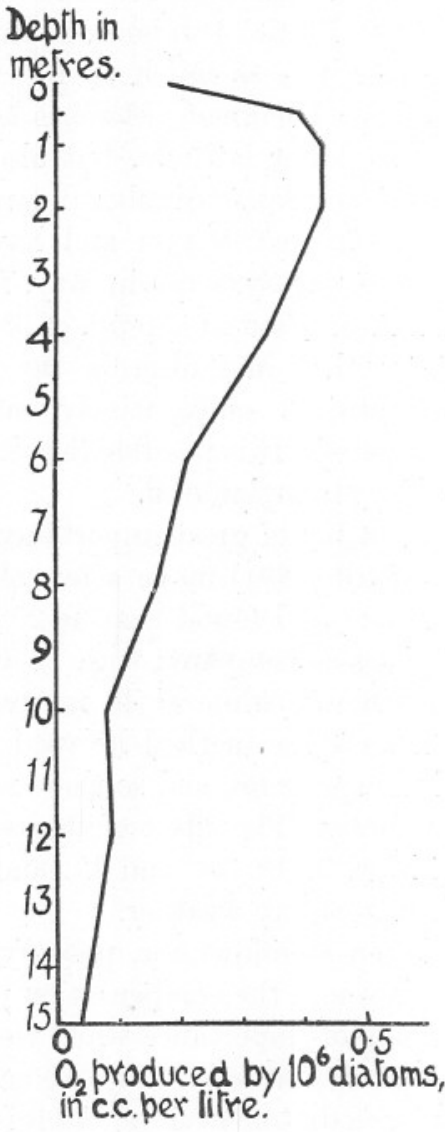

Fig. 24.-Oxygen produced per $10^{6}$ diatoms off Hunterston Perch, $18 / 7 / 27$. bottom, so that the greatest number may be found at any intermediate depth, and Gran (1912) has shown that some of the "maxima" are due to a holding up of the diatoms in their fall when a denser layer of water is reached. He concluded from a survey of the plankton production in North European waters that the light optimum for plant growth in the sea was probably less than 10 and never deeper than 30 metres. As has already been mentioned, this has been confirmed (Atkins, 1926b; 
Harvey, 1926 ; Marshall and Orr, 1927) by examining throughout the year the chemical changes set up by photosynthesis.

A comparison of the depths to which diatoms can grow with the distribution of the fixed algæ is interesting. Since diatoms are brown they correspond, in colour at least, to the shallower fixed algæ. In northern waters the lower limit for the algæ varies from about 20 metres (in the Baltic) to about 50 metres (off Iceland), while in the Mediterranean it is as much as 130 to 160 metres (see Gran, 1912; Atkins, 1926a). The great difference between the two is no doubt due not only to the lower latitude, but also to the more transparent waters of the Mediterranean. Similar differences are to be expected in the phytoplankton distribution and have often been found. Lohmann (1902), working off Syracuse in May, found coccolithophores and diatoms much more abundant at a depth of 50 metres than at the surface. Sleggs (1927) states that in California the phytoplankton production of the upper 20 metres is comparatively small, and that most takes place from 25 to 55 metres. It is possible that these results are complicated by the sinking of the phytoplankton.

A factor of great importance is the length of day at different depths. Regnard (1891) made a few observations in clear weather in March off Madeira and found that at 20 metres the length of day was reduced to 7 hours as compared with 11 at the surface, at 30 metres it was reduced to 5 hours, while at 40 metres it only lasted for a few minutes. The photographic method he used, however, measures mainly the blue end of the spectrum, and so these results cannot be directly related to photosynthesis. The effect of shortening of the day with depth is well shown in Figs. 7, 10, 14, and 17, and is naturally much more marked in dull than in sunny weather.

Even at midwinter, photosynthesis is greater than respiration at the surface and the compensation point is always at a depth of some metres. This is of importance when we consider the causes of the spring diatom increase. Little is known about the amount of reserve material necessary before a diatom divides, but it is difficult to believe that in the lengthening days of February and March light can act as a limiting factor for growth in the sea.

\section{CONCLUSIONS AND SUMMARY.}

Experiments have been carried out on the photosynthesis of diatom cultures at different depths in the sea. The results of these lead to the conclusion that the compensation point in this latitude in inshore waters lies at a depth of from 20 to 30 metres in summer. As we approach the surface the increasing light enables more photosynthesis to take place, 
but this increase only goes on up to a certain depth. There is no point which can be considered as the optimum, but a range extending over 2 or 3 metres. Above this light is too strong and photosynthesis falls off again. Even at midwinter the midday sun is injurious at the surface. These depths naturally depend on the season and also to a large extent on the kind of weather. The compensation point sinks gradually from a position close to the surface in winter to a depth of 20 to 30 metres in summer. This applies, of course, to coastal water which has more detritus in suspension (ef. Poole and Atkins, 1926), and as we go further from land this depth will increase.

We are indebted to the Royal Society for a grant to cover publication of figures and plates in this and our previous paper (1927).

The sunshine records were obtained by the courtesy of the Buteshire Natural History Society.

We desire also to thank Mr. Elmhirst and members of the staff for their help throughout.

\section{REFERENCES.}

1910. Allen, E. J., and Nelson, E. W. On the artificial culture of marine plankton organisms. Journal of the Marine Biological Association, N.S., Vol. VIII.

1925. Anderson, W. T., and Robinson, F. W. An Oxalic Acid-Uranyl sulphate Ultra-violet Radiometer. Journ. Amer. Chem. Soc., Vol. 47.

1926(a). Atkins, W. R. G. A quantitative consideration of some factors concerned in plant growth in water. Part I. Some physical factors. Conseil Permanent International pour l'Exploration de la Mer. Journal du Conseil, Vol. I, No. 2.

1926(b). Atrins, W. R. G. A quantitative consideration of some factors concerned in plant growth in water. Part II. Some chemical factors. Ibid., Vol., I, No. 3 .

1927. GaArder, T., and Gran, H. H. Production of Plankton in the Oslo Fjord. Conseil Permanent International pour l'Exploration de la Mer. Rapports et Procès-Verbaux des Réunions, Vol. XLII.

1912. Gran, H. H. The Plankton Production in the North European Waters in the Spring of 1912. Conseil Permanent International pour l'Exploration de la Mer. Bulletin Planktonique.

1927. Gran, H. H. The Production of Plankton in the Coastal Waters off Bergen. Report on Norwegian Fishery and Marine Investigations, Vol. III, No. 8. 
1926. Harvey, H. W. Nitrate in the Sea. Journal of the Marine Biological Association, N.S., Vol. XIV.

1903. Jönsson, B. Assimilationsversuche bei verschiedener Meerestiefen. Nyt Magasin for Naturvidenskaberne, Bd. LIII.

1905. Karsten, G. Die Phytoplankton des Antarktischen Meeres nach dem Material der deutschen Tiefsee Expedition, 189899. Wissenschaftliche Ergebnisse der deutschen Tiefsee Expedition, Bd. II, Teil 2.

1902. Lohmann, H. Die Coccolithophoridæ, eine Monographie der Coccolithenbildenden Flagellaten. Archiv für Protistenkunde, Vol. I.

1908. Lohmann, H. Untersuchungen zur Feststellung des vollständigen Gehaltes des Meeres an Plankton. Wissenschaftliche Meeresuntersuchungen v. d. Komm. d. wiss. Unters. d. deutsch. Meere in Kiel, Vol. X.

1920. McLean, F. T. Field Studies of the Carbon Dioxide absorption of coconut leaves. Annals of Botany, Vol. XXXIV.

1927. Marshall, S. M., and OrR, A. P. The Relation of the Plankton to some Chemical and Physical Factors in the Clyde Sea Area. Journal of the Marine Biological Association, N.S. Vol. XIV.

1926. Poole, H. H., and Atrins, W. R. G. On the penetration of light into sea-water. Journal of the Marine Biological Association, N.S., Vol. XIV.

1891. Regnard, P. La Vie dans les Eaux. Paris.

1926. RuUd, B. Quantitative Investigations of Plankton at Lofoten, March to April, 1922-24. Report on Norwegian Fishery and Marine Investigations, Vol. III, No. 7.

1926. Ruttner, F. Über die Kohlensäureassimilation einiger Wasserpflanzen in verschiedenen Tiefen des Lunzer Untersees. Internationale Revue d. gesamt. Hydriobiol. u. Hydrograph. Band XV.

1927. Sleggs, G. P. Marine Phytoplankton in the region of La Jolla, California, during the summer of 1924. Bulletin of the Scripps Institution of Oceanography, Technical Series, Vol. I, No. 9.

1914. WhIPple, G. H. The Microscopy of Drinking Water, 3rd edition. New York.

1920. YAP, G. G. A Study of the photosynthesis of Sugar-cane. Philippine Agric., Vol. VIII. 


\section{TABLE I.}

Loch Striven, 18-19/3/27. No sunshine.

Diatom culture of Oct. 18 th-2,300 cells per c.c. 12.15 p.m. to 11.15 a.m. Initial $\mathrm{O}_{2}$ content. $\left.\begin{array}{l}6 \cdot 43 \\ 6 \cdot 46\end{array}\right\} 6 \cdot 45$.

\begin{tabular}{ccccccc}
$\begin{array}{c}\text { Depth in } \\
\text { metres. }\end{array}$ & Light. & \multicolumn{2}{c}{ Dark. } & $\begin{array}{c}\text { Total } \mathrm{O}_{2} \\
\text { produced. }\end{array}$ & $\begin{array}{c}\mathrm{O}_{2} \text { produced } \\
\text { by } 10^{6} \\
\text { diatoms. }\end{array}$ & $\begin{array}{c}\text { Tempera- } \\
\text { ture }{ }^{\circ} \mathrm{C} \text {. }\end{array}$ \\
0 & $1.6 \cdot 94$ & $1.5 \cdot 90$ & $6 \cdot 02$ & +0.92 & $0 \cdot 40$ & $6 \cdot 64$ \\
5 & $1.6 \cdot 44$ & $1.5 \cdot 96$ & $6 \cdot 02$ & $+0 \cdot 44$ & $0 \cdot 19$ & $6 \cdot 50$ \\
10 & $1.6 \cdot 26$ & $1.6 \cdot 06$ & $6 \cdot 02$ & $+0 \cdot 24$ & $0 \cdot 10$ & $7 \cdot 05$ \\
20 & $1.6 \cdot 19$ & $1.6 \cdot 08$ & $6 \cdot 02$ & $+0 \cdot 17$ & $0 \cdot 07$ & $7 \cdot 23$ \\
40 & $1.6 \cdot 06$ & $1.6 \cdot 06$ & $6 \cdot 02$ & $+0 \cdot 04$ & - & $7 \cdot 35$
\end{tabular}

TABLE II.

Loch Striven, 28-29/3/27. Sunshine -5 hrs. 50 mins. Diatom culture of February 21 st $-3,500$ cells per c.c. 11-40 a.m. to 12 noon. Initial $\mathrm{O}_{2}$ content $6 \cdot 56$.

\section{$1.7 \cdot 34)$}

\section{TABLE III.}

Loch Striven, 31/3-1/4/27. Sunshine- -5 hrs. 15 mins. Diatom culture of February 21st-2,800 cells per c.c. 12 noon to $11-30$ a.m. Initial $\mathrm{O}_{2}$ content $6 \cdot 55$.

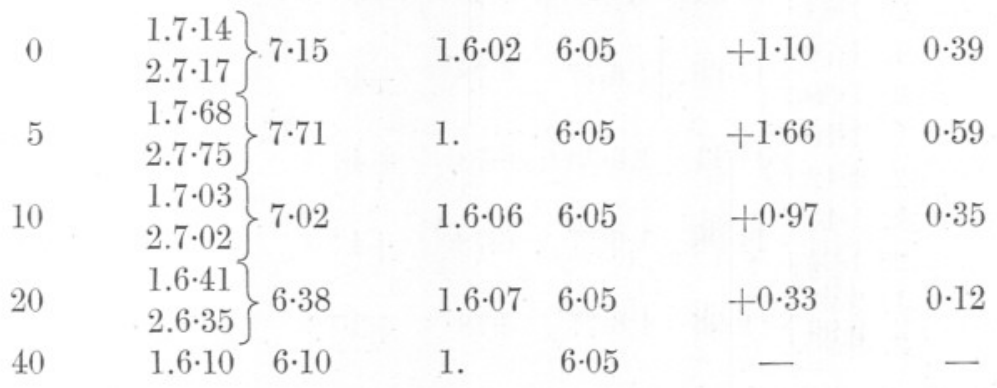


TABLE IV.

Loch Striven, 18-19/5/27. 5 hrs. 55 mins. sunshine (all on 18th). Diatom culture of May 3rd-3,400 cells per c.c.

11.25 a.m. to 11 a.m. Initial $\mathrm{O}_{2}$ content $\left.\begin{array}{l}1.7 \cdot 02 \\ 4.7 \cdot 12\end{array}\right\} 7 \cdot 07$.

\begin{tabular}{|c|c|c|c|c|c|c|c|}
\hline $\begin{array}{l}\text { Depth in } \\
\text { metres }\end{array}$ & Lig & & $\mathrm{Da}$ & & $\begin{array}{l}\text { Total } \mathrm{O}_{2} \\
\text { produced. }\end{array}$ & $\begin{array}{c}\mathrm{O}_{2} \text { produced } \\
\text { by } 10^{6} \\
\text { diatoms. }\end{array}$ & $\begin{array}{l}\text { Tempera } \\
\text { ture }{ }^{\circ} \mathrm{C}\end{array}$ \\
\hline 0 & $\left.\begin{array}{l}\text { 1. } 9 \cdot 59 \\
\text { 2. } 9 \cdot 18\end{array}\right\}$ & $9 \cdot 38$ & $1.6 \cdot 28$ & $6 \cdot 36$ & $+3 \cdot 02$ & & \\
\hline$\frac{1}{2}$ & $\begin{array}{l}1.9 \cdot 96 \\
2.10 \cdot 66 \\
3.10 \cdot 94\end{array}$ & $10 \cdot 52$ & $\begin{array}{l}1.6 \cdot 38 \\
2.6 \cdot 31\end{array}$ & $6 \cdot 36$ & $+4 \cdot 16$ & $1 \cdot 22$ & - \\
\hline 1 & $\begin{array}{l}1.11 \cdot 28 \\
2.11 \cdot 14\end{array}$ & $11 \cdot 21$ & $1.6 \cdot 28$ & $6 \cdot 36$ & $+4 \cdot 85$ & $1 \cdot 43$ & $9 \cdot 46$ \\
\hline 2 & $\begin{array}{l}1.10 \cdot 87 \\
2.10 \cdot 88\end{array}$ & $10 \cdot 88$ & $1.6 \cdot 31$ & $6 \cdot 36$ & $+4 \cdot 52$ & $1 \cdot 33$ & $9 \cdot 45$ \\
\hline 3 & $\begin{array}{l}1.10 \cdot 53 \\
2.10 \cdot 56\end{array}$ & 10.55 & $1.6 \cdot 34$ & $6 \cdot 36$ & $+4 \cdot 19$ & $1 \cdot 23$ & 8.92 \\
\hline 4 & $\begin{array}{l}\text { 1. } 9 \cdot 30 \\
\text { 2. } 9 \cdot 43\end{array}$ & $9 \cdot 36$ & $1.6 \cdot 39$ & $6 \cdot 36$ & $+3 \cdot 00$ & $0 \cdot 88$ & $9 \cdot 38$ \\
\hline 5 & $\begin{array}{l}\text { 1. } 9 \cdot 06 \\
\text { 2. } 9 \cdot 06\end{array}$ & $9 \cdot 06$ & $1.6 \cdot 41$ & $6 \cdot 36$ & $+2 \cdot 70$ & $0 \cdot 79$ & $9 \cdot 40$ \\
\hline 6 & 1. 8.58 & $8 \cdot 58$ & $1.6 \cdot 39$ & $6 \cdot 36$ & $+2 \cdot 22$ & $0 \cdot 65$ & 8.92 \\
\hline 7 & $\left.\begin{array}{l}\text { 1. } 7 \cdot 99 \\
\text { 2. } 8 \cdot 04\end{array}\right\}$ & $8 \cdot 01$ & $1.6 \cdot 35$ & $6 \cdot 36$ & $+1 \cdot 65$ & $0 \cdot 49$ & $8 \cdot 26$ \\
\hline
\end{tabular}

TABLE V.

Loch Striven, 13-14/6/27. Sunshine-16 hrs. 5 mins. Culture of May 29th-3,700 cells per c.c.

\subsubsection{5}

11 a.m. to 10.50 a.m. Initial $\mathrm{O}_{2}$ content $\left.2.6 \cdot 93\right\} 6 \cdot 93$. 3.6 .92 J

\begin{tabular}{|c|c|c|c|c|c|c|c|}
\hline & & & & & & & \\
\hline 1 & $\begin{array}{l}1.12 \cdot 05 \\
2.11 \cdot 63\end{array}$ & $11 \cdot 84$ & 1. - & $6 \cdot 78$ & +5.06 & $1 \cdot 37$ & $10 \cdot 58$ \\
\hline 3 & $\begin{array}{l}1.11 \cdot 76 \\
2.11 \cdot 59\end{array}$ & $11 \cdot 68$ & $1.6 \cdot 77$ & $6 \cdot 78$ & +4.90 & $1 \cdot 32$ & $10 \cdot 38$ \\
\hline 5 & $\begin{array}{l}1.11 \cdot 10 \\
2.11 \cdot 12\end{array}$ & $11 \cdot 11$ & $1.6 \cdot 73$ & $6 \cdot 78$ & $+4 \cdot 33$ & $1 \cdot 17$ & $10 \cdot 23$ \\
\hline 7 & $\begin{array}{l}1.11 \cdot 11 \\
2.11 \cdot 04\end{array}$ & $11 \cdot 08$ & $1.6 \cdot 77$ & $6 \cdot 78$ & $+4 \cdot 30$ & $1 \cdot 16$ & 9.59 \\
\hline & $\begin{array}{l}\text { 1. } 9 \cdot 97 \\
\text { 2. } 9 \cdot 96\end{array}$ & $9 \cdot 96$ & $1.6 \cdot 77$ & $6 \cdot 78$ & $+3 \cdot 18$ & $0 \cdot 86$ & $9 \cdot 00$ \\
\hline
\end{tabular}




\begin{tabular}{|c|c|c|c|c|c|c|}
\hline 20 & $\left.\begin{array}{l}\text { 1. } 7 \cdot 21 \\
\text { 2. } 7 \cdot 20\end{array}\right\}$ & $7 \cdot 21$ & $1.6 \cdot 79$ & $6 \cdot 78$ & $+0 \cdot 43$ & $0 \cdot 12$ \\
\hline 30 & $\begin{array}{l}\text { 1. } 6 \cdot 87 \\
\text { 2. } 6 \cdot 85\end{array}$ & $6 \cdot 86$ & $1.6 \cdot 76$ & $6 \cdot 78$ & $+0 \cdot 08$ & $0 \cdot 02$ \\
\hline $40 *$ & 1. $6 \cdot 80$ & $6 \cdot 80$ & $1.6 \cdot 88$ & $6 \cdot 78$ & $+0 \cdot 02$ & 0.01 \\
\hline 50 & $\begin{array}{l}\text { 1. } 6 \cdot 87 \\
\text { 2. } 6 \cdot 92\end{array}$ & $6 \cdot 90$ & $1.6 \cdot 78$ & $6 \cdot 78$ & $+0 \cdot 12$ & 0.03 \\
\hline 60 & $\left.\begin{array}{ll}\text { 1. } & 6 \cdot 87 \\
\text { 2. } & 6 \cdot 89\end{array}\right\}$ & $6 \cdot 88$ & $1.6 \cdot 81$ & $6 \cdot 78$ & $+0 \cdot 10$ & 0.03 \\
\hline
\end{tabular}

TABLE VI.

Farland Point, 9-10/6/27. Sunshine -15 hrs. 5 minutes. Diatom cultures of May-3.600 cells per c.c.

12.3 А.м. то 3 А.м.

Initial $\mathrm{O}_{2}$ content- $\left.\begin{array}{r}1.5 \cdot 86 \\ 2.5 \cdot 87\end{array}\right\} 5 \cdot 86$.

\begin{tabular}{|c|c|c|c|c|c|c|}
\hline 0 & $\begin{array}{l}1.5 \cdot 81 \\
2.5 \cdot 81\end{array}$ & $5 \cdot 81$ & $1.5 \cdot 82$ & $5 \cdot 76$ & +0.05 & 0.014 \\
\hline & $\begin{array}{l}1.5 \cdot 77 \\
2.5 \cdot 75\end{array}$ & $5 \cdot 76$ & $1.5 \cdot 69$ & $5 \cdot 76$ & - & - \\
\hline & $\begin{array}{l}1.5 \cdot 75 \\
2.5 \cdot 78\end{array}$ & $5 \cdot 77$ & $1.5 \cdot 76$ & $5 \cdot 76$ & +0.01 & 0.003 \\
\hline & $\begin{array}{l}1.5 \cdot 83 \\
2.5 \cdot 78\end{array}$ & $5 \cdot 81$ & $1.5 \cdot 75$ & $5 \cdot 76$ & +0.05 & 0.014 \\
\hline & $\begin{array}{l}1.5 \cdot 79 \\
2.5 \cdot 78\end{array}$ & $5 \cdot 78$ & $1.5 \cdot 78$ & $5 \cdot 76$ & $+0 \cdot 02$ & 0.006 \\
\hline & $\begin{array}{l}1.5 \cdot 76 \\
2.5 \cdot 84\end{array}$ & $5 \cdot 80$ & $1.5 \cdot 81$ & $5 \cdot 76$ & +0.04 & 0.011 \\
\hline & $\begin{array}{l}1.5 \cdot 75 \\
2.5 \cdot 76\end{array}$ & $5 \cdot 76$ & $1.5 \cdot 71$ & $5 \cdot 76$ & - & \\
\hline
\end{tabular}

\begin{tabular}{|c|c|c|c|c|c|c|}
\hline & & Initia & ontent & $\begin{array}{l}\text { 1. } 5 \cdot 79 \\
\text { 2. } 5 \cdot 86\end{array}$ & 83. & \\
\hline 0 & $\begin{array}{l}1.6 \cdot 92 \\
2.6 \cdot 95\end{array}$ & 6.93 & $1.5 \cdot 81$ & $5 \cdot 75$ & $+1 \cdot 18$ & 0.328 \\
\hline$\frac{1}{2}$ & $\begin{array}{l}1.6 \cdot 53 \\
2.6 \cdot 59\end{array}$ & $6 \cdot 56$ & $1.5 \cdot 79$ & $5 \cdot 75$ & +0.81 & $0 \cdot 225$ \\
\hline 1 & $\begin{array}{l}1.6 \cdot 61 \\
2.6 \cdot 56\end{array}$ & 6.58 & $1.5 \cdot 81$ & $5 \cdot 75$ & +0.83 & $0 \cdot 231$ \\
\hline 2 & $\begin{array}{l}1.6 \cdot 55 \\
2.6 \cdot 51\end{array}$ & 6.53 & $1.5 \cdot 68$ & $5 \cdot 75$ & +0.78 & 0.217 \\
\hline
\end{tabular}




\begin{tabular}{|c|c|c|c|c|c|}
\hline $\begin{array}{l}\text { Depth_in } \\
\text { metres. }\end{array}$ & Light. & Das & & $\begin{array}{l}\text { Total } \mathrm{O}_{2} \\
\text { produced. }\end{array}$ & $\begin{array}{c}\mathrm{O}_{2} \text { produced } \\
\text { by } 10^{6} \\
\text { diatoms. }\end{array}$ \\
\hline 3 & $\left.\begin{array}{l}1.6 \cdot 34 \\
2.6 \cdot 37\end{array}\right\} 6 \cdot 35$ & 1. & $5 \cdot 75$ & $+0 \cdot 60$ & $0 \cdot 167$ \\
\hline 4 & $\left.\begin{array}{l}1.6 \cdot 26 \\
2.6 \cdot 28\end{array}\right\} 6 \cdot 27$ & $1.5 \cdot 68$ & $5 \cdot 75$ & $+0 \cdot 52$ & $0 \cdot 144$ \\
\hline 6 & $\left.\begin{array}{l}1.6 \cdot 08 \\
2.6 \cdot 03\end{array}\right\} 6 \cdot 05$ & $1.5 \cdot 74$ & $5 \cdot 75$ & $+0 \cdot 30$ & $0 \cdot 083$ \\
\hline
\end{tabular}

6.5 А.м. то 8.50 А.м.

\begin{tabular}{|c|c|c|c|c|c|c|}
\hline & & Initial & ntent & $\begin{array}{l}\text { 1. } 7 \cdot 63 \\
\text { 2. } 7 \cdot 67\end{array}$ & 65 & \\
\hline 0 & $\left.\begin{array}{l}1.7 \cdot 94 \\
2.8 \cdot 03\end{array}\right\}$ & $7 \cdot 99$ & $1.7 \cdot 58$ & $7 \cdot 48$ & +0.51 & $0 \cdot 142$ \\
\hline$\frac{1}{2}$ & $\left.\begin{array}{l}1.8 \cdot 23 \\
2.8 \cdot 23\end{array}\right\}$ & $8 \cdot 23$ & $1.7 \cdot 50$ & $7 \cdot 48$ & $+0 \cdot 75$ & $0 \cdot 208$ \\
\hline 1 & $\begin{array}{l}1.8 \cdot 34 \\
2.8 \cdot 15\end{array}$ & $8 \cdot 25$ & $1.7 \cdot 48$ & $7 \cdot 48$ & $+0 \cdot 77$ & $0 \cdot 214$ \\
\hline 2 & $\begin{array}{l}1.8 \cdot 35 \\
2.8 \cdot 23\end{array}$ & $8 \cdot 29$ & $1.7 \cdot 48$ & $7 \cdot 48$ & $+0 \cdot 81$ & 0.225 \\
\hline 3 & $1.8 \cdot 21^{\circ}$ & $8 \cdot 21$ & $1.7 \cdot 45$ & $7 \cdot 48$ & $+0 \cdot 73$ & $0 \cdot 203$ \\
\hline 4 & $\left.\begin{array}{l}1.8 \cdot 32 \\
2.8 \cdot 20\end{array}\right\}$ & $8 \cdot 26$ & $1.7 \cdot 39$ & $7 \cdot 48$ & $+0 \cdot 78$ & $0 \cdot 217$ \\
\hline 6 & $\left.\begin{array}{l}1.8 \cdot 26 \\
2.8 \cdot 13\end{array}\right\}$ & $8 \cdot 20$ & $1.7 \cdot 48$ & $7 \cdot 48$ & +0.72 & $0 \cdot 200$ \\
\hline
\end{tabular}

9 А.м. то 11.55 А.м.

\begin{tabular}{|c|c|c|c|c|c|c|}
\hline 0 & $\begin{array}{l}1.7 \cdot 53 \\
2.7 \cdot 56\end{array}$ & $7 \cdot 54$ & $1.7 \cdot 37$ & $7 \cdot 27$ & $+0 \cdot 27$ & 0.075 \\
\hline & $\begin{array}{l}1.8 \cdot 03 \\
2.7 .91\end{array}$ & $7 \cdot 97$ & $1.7 \cdot 06$ & $7 \cdot 27$ & $+0 \cdot 70$ & $0 \cdot 195$ \\
\hline & $\begin{array}{l}1.8 \cdot 19 \\
2.8 \cdot 14\end{array}$ & $8 \cdot 17$ & $1.7 \cdot 30$ & $7 \cdot 27$ & $+0 \cdot 90$ & $0 \cdot 250$ \\
\hline & $\left.\begin{array}{l}1.8 \cdot 24 \\
2.8 \cdot 18\end{array}\right\}$ & $8 \cdot 21$ & $1.7 \cdot 31$ & $7 \cdot 27$ & +0.94 & $0 \cdot 262$ \\
\hline & $\left.\begin{array}{l}1.8 \cdot 18 \\
2.8 \cdot 12\end{array}\right\}$ & $8 \cdot 15$ & $1.7 \cdot 21$ & $7 \cdot 27$ & $+0 \cdot 88$ & $0 \cdot 244$ \\
\hline & $\left.\begin{array}{l}1.8 \cdot 14 \\
2.8 \cdot 11\end{array}\right\}$ & $8 \cdot 12$ & $1.7 \cdot 26$ & $7 \cdot 27$ & $+0 \cdot 85$ & $0 \cdot 236$ \\
\hline & $\left.\begin{array}{l}1.8 \cdot 19 \\
2.8 \cdot 15\end{array}\right\}$ & $8 \cdot 17$ & $1.7 \cdot 19$ & $7 \cdot 27$ & +0.90 & $0 \cdot 250$ \\
\hline
\end{tabular}


12 NoON то 2.57 P.M.

\begin{tabular}{|c|c|c|c|c|c|c|}
\hline & \multicolumn{3}{|c|}{ Initial $\mathrm{O}_{2}$ content } & $\left.\begin{array}{l}\text { 1. } 7 \cdot 33 \\
2.7 \cdot 16\end{array}\right\}$ & \multicolumn{2}{|l|}{$7 \cdot 25$} \\
\hline 0 & $\begin{array}{l}1.7 \cdot 38 \\
2.7 \cdot 36\end{array}$ & $7 \cdot 37$ & 1. & $7 \cdot 05$ & $+0 \cdot 32$ & $0 \cdot 089$ \\
\hline$\frac{1}{2}$ & $\left.\begin{array}{l}1.7 \cdot 81 \\
2.7 \cdot 73\end{array}\right\}$ & $7 \cdot 77$ & $1.7 \cdot 08$ & $7 \cdot 05$ & $+0 \cdot 72$ & $0 \cdot 200$ \\
\hline 1 & $\left.\begin{array}{l}1.7 \cdot 91 \\
2.8 \cdot 01\end{array}\right\}$ & $7 \cdot 96$ & $1.7 \cdot 04$ & $7 \cdot 05$ & $+0 \cdot 91$ & $0 \cdot 253$ \\
\hline 2 & $\left.\begin{array}{l}1.8 \cdot 05 \\
2.7 \cdot 99\end{array}\right\}$ & $8 \cdot 02$ & $1.7 \cdot 01$ & $7 \cdot 05$ & $+0 \cdot 97$ & $0 \cdot 270$ \\
\hline 3 & $\begin{array}{l}1.8 \cdot 05 \\
2.7 \cdot 96\end{array}$ & $8 \cdot 01$ & $1.7 \cdot 06$ & $7 \cdot 05$ & +0.96 & $0 \cdot 267$ \\
\hline 4 & $\left.\begin{array}{l}1.8 \cdot 06 \\
2.7 \cdot 93\end{array}\right\}$ & $8 \cdot 00$ & $1.7 \cdot 07$ & $7 \cdot 05$ & +0.95 & $0 \cdot 264$ \\
\hline 6 & $\left.\begin{array}{l}1.8 \cdot 10 \\
2.7 \cdot 98\end{array}\right\}$ & $8 \cdot 04$ & $1.7 \cdot 03$ & $7 \cdot 05$ & +0.99 & $0 \cdot 275$ \\
\hline & & Initial & $\begin{array}{l}\text { м. то } 5 \\
\text { ontent }\end{array}$ & $\begin{array}{l}.55 \text { P.м. } \\
\left.\begin{array}{l}\text { 1. } 6 \cdot 80 \\
\text { 2. } 7.02\end{array}\right\}\end{array}$ & $6 \cdot 91$ & \\
\hline 0 & $\left.\begin{array}{l}1.7 \cdot 15 \\
2.7 \cdot 40\end{array}\right\}$ & $7 \cdot 27$ & 1. & $6 \cdot 67$ & $+0 \cdot 60$ & $0 \cdot 167$ \\
\hline$\frac{1}{2}$ & $\left.\begin{array}{l}1.7 \cdot 60 \\
2.7 \cdot 58\end{array}\right\}$ & $7 \cdot 59$ & $1.6 \cdot 69$ & $6 \cdot 67$ & +0.92 & $0 \cdot 256$ \\
\hline 1 & $\begin{array}{l}1.7 \cdot 68 \\
2.7 \cdot 66\end{array}$ & $7 \cdot 67$ & $1.6 \cdot 69$ & $6 \cdot 67$ & $+1 \cdot 00$ & $0 \cdot 278$ \\
\hline 2 & $\begin{array}{l}1.7 \cdot 69 \\
2.7 \cdot 69\end{array}$ & $7 \cdot 69$ & $1.6 \cdot 68$ & $6 \cdot 67$ & $+1 \cdot 02$ & $0 \cdot 283$ \\
\hline 3 & $\left.\begin{array}{l}1.7 \cdot 67 \\
2.7 \cdot 62\end{array}\right\}$ & $7 \cdot 64$ & $1.6 \cdot 64$ & $6 \cdot 67$ & +0.97 & $0 \cdot 270$ \\
\hline 4 & $\left.\begin{array}{l}1.7 \cdot 66 \\
2.7 \cdot 68\end{array}\right\}$ & $7 \cdot 67$ & $1.6 \cdot 62$ & $6 \cdot 67$ & $+1 \cdot 00$ & $0 \cdot 277$ \\
\hline 6 & $\left.\begin{array}{l}1.7 \cdot 67 \\
2.7 \cdot 65\end{array}\right\}$ & $\{7 \cdot 66$ & $1.6 \cdot 71$ & $6 \cdot 67$ & $+0 \cdot 99$ & $0 \cdot 275$ \\
\hline & & Initial & $\begin{array}{l}\text { м. то } \\
\text { ontent }\end{array}$ & 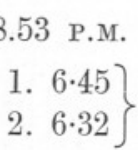 & $6 \cdot 38$ & \\
\hline 0 & $\left.\begin{array}{l}1.7 \cdot 25 \\
2.7 \cdot 18\end{array}\right\}$ & $\{7 \cdot 22$ & $1.6 \cdot 43$ & $6 \cdot 29$ & +0.93 & $0 \cdot 258$ \\
\hline$\frac{1}{2}$ & $\left.\begin{array}{l}1.7 \cdot 15 \\
2.7 \cdot 20\end{array}\right\}$ & $7 \cdot 17$ & $1.6 \cdot 41$ & $6 \cdot 29$ & $+0 \cdot 88$ & $0 \cdot 244$ \\
\hline
\end{tabular}




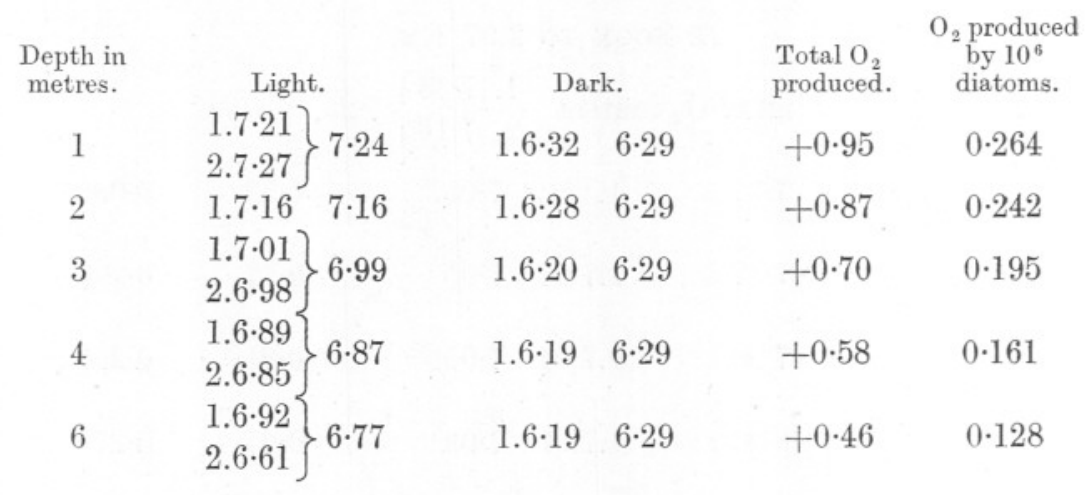

8.57 P.M. то 12 мIDNIGHT.

\begin{tabular}{|c|c|c|c|c|c|c|}
\hline & & Initia & ntent & $\begin{array}{l}\text { 1. } 6 \cdot 0 \\
\text { 2. } 6 \cdot 0\end{array}$ & 06. & \\
\hline 0 & $\begin{array}{l}1.6 \cdot 02 \\
2.6 \cdot 01\end{array}$ & $6 \cdot 01$ & $1.6 \cdot 01$ & $5 \cdot 90$ & $+0 \cdot 11$ & 0.031 \\
\hline$\frac{1}{2}$ & $\begin{array}{l}1.5 \cdot 96 \\
2.5 \cdot 92\end{array}$ & $5 \cdot 94$ & $1.5 \cdot 91$ & $5 \cdot 90$ & +0.04 & 0.011 \\
\hline 1 & $\begin{array}{l}1.5 \cdot 97 \\
2.5 \cdot 93\end{array}$ & $5 \cdot 95$ & $1.5 \cdot 93$ & $5 \cdot 90$ & +0.05 & 0.014 \\
\hline 2 & $\begin{array}{l}1.5 \cdot 91 \\
2.5 \cdot 91\end{array}$ & $5 \cdot 91$ & $1.5 \cdot 90$ & $5 \cdot 90$ & +0.01 & $0 \cdot 003$ \\
\hline 3 & $\begin{array}{l}1.5 \cdot 89 \\
2.5 \cdot 91\end{array}$ & $5 \cdot 90$ & $1.5 \cdot 88$ & $5 \cdot 90$ & - & - \\
\hline 4 & $\begin{array}{l}1.5 \cdot 87 \\
2.5 \cdot 89\end{array}$ & $5 \cdot 88$ & $1.5 \cdot 84$ & $5 \cdot 90$ & - & - \\
\hline 6 & $\begin{array}{l}1.5 \cdot 87 \\
2.5 \cdot 85\end{array}$ & $5 \cdot 86$ & $1.5 \cdot 85$ & $5 \cdot 90$ & - & $\cdots$ \\
\hline
\end{tabular}

Composite Curve.

$\begin{array}{ccc} & \begin{array}{c}\text { Total } \mathrm{O}_{2} \\ \text { produced. }\end{array} & \begin{array}{c}\mathrm{O}_{2} \text { produced by } \\ 10^{6} \text { diatoms. }\end{array} \\ \text { Surface } & +3.97 & 1 \cdot 103 \\ \frac{1}{2} \mathrm{~m} . & +4 \cdot 82 & 1 \cdot 339 \\ 1 \mathrm{~m} . & +5 \cdot 42 & 1 \cdot 505 \\ 2 \mathrm{~m} . & +5 \cdot 45 & 1 \cdot 514 \\ 3 \mathrm{~m} . & +4 \cdot 86 & 1 \cdot 350 \\ 4 \mathrm{~m} . & +4 \cdot 72 & 1 \cdot 311 \\ 6 \mathrm{~m} . & +4 \cdot 36 & 1 \cdot 212\end{array}$




\section{TABLE VII.}

Farland Point, 28/6/27. No sunshine.

Diatom cultures of June 2 nd-June 13 th $-3,700$ cells per c.c.

$$
12.10 \text { А.M. то } 3.3 \text { A.M. }
$$

Initial $\mathrm{O}_{2}$ content $\left.\begin{array}{l}1.6 \cdot 78 \\ 2.6 \cdot 69\end{array}\right\} 6 \cdot 73$.

$\begin{array}{ll} & 6 \cdot 65 \\ 1.6 \cdot 67 & 6.65 \\ 1.6 \cdot 66 & 6.65\end{array}$

3.3 A.м. то 5.57 A.м.

Initial $\mathrm{O}_{2}$ content $\left.\begin{array}{l}1.6 \cdot 11 \\ 2.6 \cdot 14\end{array}\right\} 6 \cdot 12$.

$\begin{array}{llll}1.6 \cdot 12 & 6.09 & +0 \cdot 50 & 0 \cdot 135 \\ 1.6 \cdot 10 & 6.09 & +0 \cdot 26 & 0 \cdot 070 \\ 1.6 \cdot 04 & 6.09 & +0.22 & 0.060\end{array}$

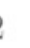




\begin{tabular}{|c|c|c|c|c|c|}
\hline $\begin{array}{l}\text { Depth in } \\
\text { metres. }\end{array}$ & Light. & Dar & & $\begin{array}{l}\text { Total } \mathrm{O}_{2} \\
\text { produced. }\end{array}$ & $\begin{array}{c}\mathrm{O}_{2} \text { produced } \\
\text { by } 10^{6} \\
\text { diatoms. }\end{array}$ \\
\hline 1 & $\left.\begin{array}{l}1.6 \cdot 98 \\
2.6 \cdot 95\end{array}\right\} 6 \cdot 96$ & $1.5 \cdot 87$ & $5 \cdot 90$ & $+1 \cdot 06$ & $0 \cdot 287$ \\
\hline 2 & $1.6 \cdot 98 \quad 6.98$ & $1.5 \cdot 91$ & $5 \cdot 90$ & $+1 \cdot 08$ & $0 \cdot 292$ \\
\hline 4 & $\left.\begin{array}{l}1.6 \cdot 84 \\
2.6 \cdot 85\end{array}\right\} 6 \cdot 84$ & $1.5 \cdot 88$ & $5 \cdot 90$ & $+0 \cdot 94$ & $0 \cdot 254$ \\
\hline 6 & $\left.\begin{array}{l}1.6 \cdot 60 \\
2.6 \cdot 57\end{array}\right\} 6.58$ & $1.5 \cdot 89$ & $5 \cdot 90$ & $+0 \cdot 68$ & $0 \cdot 184$ \\
\hline
\end{tabular}

9 A.M. то 12 Noon.

Initial $\mathrm{O}_{2}$ content $\left.\begin{array}{l}1.6 \cdot 17 \\ 2.6 \cdot 19\end{array}\right\} 6 \cdot 18$.

\begin{tabular}{|c|c|c|c|c|c|c|}
\hline 0 & $\begin{array}{l}1.6 \cdot 85 \\
2.6 \cdot 88\end{array}$ & $6 \cdot 87$ & $1.6 \cdot 14$ & $6 \cdot 08$ & $+0 \cdot 79$ & $0 \cdot 214$ \\
\hline & $\begin{array}{l}1.7 \cdot 03 \\
2.7 \cdot 08\end{array}$ & $7 \cdot 06$ & $1.6 \cdot 07$ & $6 \cdot 08$ & +0.98 & $0 \cdot 265$ \\
\hline & $\begin{array}{l}1.7 \cdot 07 \\
2.7 \cdot 12\end{array}$ & $7 \cdot 09$ & $1.6 \cdot 04$ & 6.08 & $+1 \cdot 01$ & $0 \cdot 273$ \\
\hline & $1.7 \cdot 17$ & $7 \cdot 17$ & $1.6 \cdot 09$ & $6 \cdot 08$ & $+1 \cdot 09$ & $0 \cdot 295$ \\
\hline & $\begin{array}{l}1.7 \cdot 14 \\
2.7 \cdot 11\end{array}$ & $7 \cdot 13$ & $1.6 \cdot 09$ & $6 \cdot 08$ & $+1 \cdot 05$ & $0 \cdot 284$ \\
\hline & $\begin{array}{l}1.6 \cdot 89 \\
2.6 \cdot 93\end{array}$ & $6 \cdot 91$ & $1.6 \cdot 09$ & $6 \cdot 08$ & +0.83 & $0 \cdot 224$ \\
\hline
\end{tabular}

12 NoON To 3.5 P.M.

\begin{tabular}{|c|c|c|c|c|c|c|}
\hline & & Initia & content & $\left.\begin{array}{l}1.6 \cdot 05 \\
2.6 \cdot 06\end{array}\right\}$ & $6 \cdot 05$ & \\
\hline 0 & $\left.\begin{array}{l}1.6 \cdot 84 \\
2.6 \cdot 71\end{array}\right\}$ & $6 \cdot 77$ & $1.5 \cdot 96$ & $5 \cdot 95$ & $+0 \cdot 82$ & $0 \cdot 222$ \\
\hline$\frac{1}{2}$ & $\left.\begin{array}{l}1.6 \cdot 98 \\
2.6 \cdot 99\end{array}\right\}$ & $6 \cdot 98$ & $1.5 \cdot 93$ & 5.95 & +1.03 & $0 \cdot 278$ \\
\hline 1 & $\begin{array}{l}1.7 \cdot 00 \\
2.7 \cdot 00\end{array}$ & $7 \cdot 00$ & $1.5 \cdot 91$ & $5 \cdot 95$ & +1.05 & $0 \cdot 284$ \\
\hline 2 & 1.6 .93 & $6 \cdot 93$ & $1.5 \cdot 98$ & $5 \cdot 95$ & $+0 \cdot 98$ & $0 \cdot \approx 65$ \\
\hline 4 & $\left.\begin{array}{l}1.6 \cdot 85 \\
2.6 \cdot 83\end{array}\right\}$ & $6 \cdot 84$ & $1.5 \cdot 96$ & $5 \cdot 95$ & +0.89 & $0 \cdot 241$ \\
\hline 6 & $\left.\begin{array}{l}1.6 \cdot 62 \\
2.6 \cdot 59\end{array}\right\}$ & $6 \cdot 60$ & $1.6 \cdot 22$ & $5 \cdot 95$ & +0.65 & $0 \cdot 176$ \\
\hline
\end{tabular}


3.5 Р.м. то 5.55 Р.м.

Initial $\mathrm{O}_{2}$ content $\left.\begin{array}{r}1.5 \cdot 86 \\ 2.5 \cdot 89\end{array}\right\} 5 \cdot 87$.

\begin{tabular}{|c|c|c|c|c|c|c|}
\hline & $\begin{array}{l}1.6 \cdot 79 \\
2676\end{array}$ & $6 \cdot 78$ & $1.5 \cdot 75$ & $5 \cdot 77$ & +1.01 & $0 \cdot 273$ \\
\hline & $\left.\begin{array}{l}1.6 \cdot 68 \\
2.6 \cdot 67\end{array}\right\}$ & $6 \cdot 68$ & $1.5 \cdot 74$ & $5 \cdot 77$ & $+0 \cdot 91$ & $0 \cdot 245$ \\
\hline & $\begin{array}{l}1.6 \cdot 56 \\
2.6 \cdot 63\end{array}$ & $6 \cdot 59$ & $1.5 \cdot 75$ & $5 \cdot 77$ & $+0 \cdot 82$ & $0 \cdot 222$ \\
\hline & $\left.\begin{array}{l}1.6 \cdot 53 \\
2.6 \cdot 39\end{array}\right\}$ & $6 \cdot 46$ & $1.5 \cdot 79$ & $5 \cdot 77$ & $+0 \cdot 69$ & $0 \cdot 187$ \\
\hline & $\left.\begin{array}{l}1.6 \cdot 24 \\
2.6 \cdot 29\end{array}\right\}$ & $6 \cdot 27$ & & $5 \cdot 77$ & +0.50 & $0 \cdot 135$ \\
\hline & $\left.\begin{array}{l}1.6 \cdot 06 \\
2.6 \cdot 13\end{array}\right\}$ & $6 \cdot 09$ & $1.5 \cdot 82$ & $5 \cdot 77$ & $+0 \cdot 32$ & $0 \cdot 086$ \\
\hline
\end{tabular}

5.55 Р.м. то 9 Р.м.

\begin{tabular}{|c|c|c|c|c|c|}
\hline $16 \cdot 46)$ & & & & & \\
\hline $2.6 \cdot 37$ & $6 \cdot 42$ & $1.5 \cdot 79$ & 5.76 & +0.66 & $0 \cdot 178$ \\
\hline $\begin{array}{l}1.6 \cdot 18 \\
2.6 \cdot 18\end{array}$ & $6 \cdot 18$ & $1.5 \cdot 71$ & $5 \cdot 76$ & $+0 \cdot 42$ & $0 \cdot 114$ \\
\hline $\left.\begin{array}{l}1.6 \cdot 12 \\
2.6 \cdot 12\end{array}\right\}$ & $6 \cdot 12$ & $1.5 \cdot 72$ & $5 \cdot 76$ & +0.36 & 0.097 \\
\hline $1.6 \cdot 08$ & $6 \cdot 08$ & $1.5 \cdot 79$ & $5 \cdot 76$ & $+0 \cdot 32$ & 0.086 \\
\hline $\left.\begin{array}{l}1.5 \cdot 99 \\
2.5 \cdot 96\end{array}\right\}$ & $5 \cdot 97$ & $1.5 \cdot 80$ & $5 \cdot 76$ & $+0 \cdot 21$ & 0.057 \\
\hline $\begin{array}{l}1.5 \cdot 93 \\
2.5 \cdot 91\end{array}$ & $5 \cdot 92$ & $1.5 \cdot 77$ & $5 \cdot 76$ & $+0 \cdot 16$ & 0.043 \\
\hline
\end{tabular}

9 P.M. Tо 12 MIDNIGHT.

Initial $\mathrm{O}_{2}$ content-1.5.90 5.90.

1. Lost. ?

2. Lost. $\}$

$1.5 \cdot 77 \quad 5 \cdot 78$

Lost. Lost.

$\frac{1}{2}$

$\left.\begin{array}{l}1.5 \cdot 80 \\ 2.5 \cdot 82\end{array}\right\} 5 \cdot 81$

$1.5 \cdot 77 \quad 5 \cdot 78$

$+0.03 \quad 0.008$

$1.5 \cdot 74$

$2.5 \cdot 77\} 5 \cdot 75$

$1.5 \cdot 74 \quad 5 \cdot 78$

$\begin{array}{lll}2 & 1.5 \cdot 83 & 5 \cdot 83 \\ 4 & 1.5 \cdot 80 & 5 \cdot 80\end{array}$

$\begin{array}{ll}1.5 \cdot 79 & 5 \cdot 78\end{array}$

$+0.05 \quad 0.014$

$\begin{array}{ll}1.5 \cdot 78 & 5 \cdot 78\end{array}$

$+0 \cdot 02$

$0 \cdot 005$

6

$\left.\begin{array}{l}1.5 \cdot 80 \\ 2.5 \cdot 82\end{array}\right\} 5 \cdot 81$

$\begin{array}{ll}1.5 \cdot 82 & 5 \cdot 78\end{array}$

$+0.03 \quad 0.008$ 


\begin{tabular}{ccc}
\multicolumn{3}{c}{ Composite Curve.* } \\
& $\begin{array}{c}\text { Total } \mathrm{O}_{2} \\
\text { produced. }\end{array}$ & $\mathrm{O}_{2}$ produced by \\
& $10^{6}$ diatoms. \\
Surface & +4.58 & 1.238 \\
$\frac{1}{2} \mathrm{~m}$. & +4.64 & 1.254 \\
$1 \mathrm{~m}$. & +4.52 & 1.222 \\
$2 \mathrm{~m}$. & $+4 \cdot 39$ & 1.187 \\
$4 \mathrm{~m}$. & $+3 \cdot 72$ & 1.006 \\
$6 \mathrm{~m}$. & +2.72 & 0.735
\end{tabular}

\section{TABLE VIII.}

Farland Point, 29/11/27. Sunshine-6 hours.

Diatom culture of October 8 th, 18th, 26th, 27th $-6,000$ cells per c.c.

6.20 А.м. то 9.10 А.м.

Initial $\mathrm{O}_{2}$ content- $1.7 \cdot 32 \quad 7 \cdot 32$.

\begin{tabular}{|c|c|c|c|c|c|c|}
\hline \multirow{3}{*}{$\begin{array}{c}\text { Depth } \\
\text { in metres. } \\
0\end{array}$} & \multirow{2}{*}{\multicolumn{2}{|c|}{ Light. }} & \multirow{2}{*}{\multicolumn{2}{|c|}{ Dark. }} & \multirow{3}{*}{$\begin{array}{c}\text { Total } \mathrm{O}_{2} \\
\text { produced. } \\
+0 \cdot 44\end{array}$} & \multirow{3}{*}{$\begin{array}{c}\mathrm{O}_{2} \text { produced } \\
\text { by } 10^{3} \\
\text { diatoms. } \\
0.073\end{array}$} \\
\hline & & & & & & \\
\hline & $1.7 \cdot 70$ & $7 \cdot 70$ & $1.7 \cdot 31$ & $7 \cdot 26$ & & \\
\hline$\frac{1}{2}$ & $\left.\begin{array}{l}1.7 \cdot 44 \\
2.7 \cdot 43\end{array}\right\}$ & $7 \cdot 44$ & $1.7 \cdot 25$ & $7 \cdot 26$ & $+0 \cdot 18$ & $0 \cdot 030$ \\
\hline 1 & $\left.\begin{array}{l}1.7 \cdot 44 \\
2.7 \cdot 41\end{array}\right\}$ & $7 \cdot 43$ & $1.7 \cdot 21$ & $7 \cdot 26$ & $+0 \cdot 17$ & $0 \cdot 029$ \\
\hline 2 & $\begin{array}{l}1.7 \cdot 40 \\
2.7 \cdot 42\end{array}$ & $7 \cdot 41$ & $1.7 \cdot 28$ & $7 \cdot 26$ & $+0 \cdot 15$ & $0 \cdot 025$ \\
\hline 4 & $\begin{array}{l}1.7 \cdot 35 \\
2.7 \cdot 37\end{array}$ & $7 \cdot 36$ & $1.7 \cdot 27$ & $7 \cdot 26$ & $+0 \cdot 10$ & $0 \cdot 017$ \\
\hline 6 & $\left.\begin{array}{l}1.7 \cdot 30 \\
2.7 \cdot 30\end{array}\right\}$ & $7 \cdot 30$ & $1.7 \cdot 24$ & $7 \cdot 26$ & $+0 \cdot 04$ & $0 \cdot 007$ \\
\hline \multicolumn{7}{|c|}{9.10 А.м. то 12 NoON. } \\
\hline & \multicolumn{5}{|c|}{$\left.\begin{array}{r}1.6 \cdot 63 \\
\text { Initial } \mathrm{O}_{2} \text { content- } 2.6 \cdot 60\end{array}\right\}$} & \\
\hline 0 & $\left.\begin{array}{l}1.8 \cdot 00 \\
2.7 \cdot 96\end{array}\right\}$ & $7 \cdot 98$ & $1.6 \cdot 59$ & $6 \cdot 59$ & $+1 \cdot 39$ & $0 \cdot 232$ \\
\hline$\frac{1}{2}$ & $\begin{array}{l}1.7 \cdot 92 \\
2.7 \cdot 95\end{array}$ & $7 \cdot 94$ & $1.6 \cdot 55$ & $6 \cdot 59$ & $+1 \cdot 35$ & $0 \cdot 225$ \\
\hline 1 & $\left.\begin{array}{l}1.8 \cdot 00 \\
2.8 \cdot 00\end{array}\right\}$ & $8 \cdot 00$ & $1.6 \cdot 50$ & $6 \cdot 59$ & $+1 \cdot 41$ & $0 \cdot 235$ \\
\hline
\end{tabular}

* Figures from 9 p.m.-12 midnight and 12 midnight-3 a.m. omitted because all results were within experimental error, and the surface lights were lost in the latter experiment. 
PHOTOSYNTHESIS OF DIATOM CULTURES.

\begin{tabular}{|c|c|c|c|c|c|c|}
\hline 2 & $\begin{array}{l}1.7 \cdot 91 \\
0.7 .05\end{array}$ & $7 \cdot 93$ & $1.6 \cdot 66$ & $6 \cdot 59$ & $+1 \cdot 34$ & $0 \cdot 223$ \\
\hline & $1.7 \cdot 50$ & & & & & \\
\hline & $2.7 \cdot 45$ & $7 \cdot 48$ & $1.6 \cdot 63$ & 6.59 & $+0 \cdot 89$ & $0 \cdot 148$ \\
\hline 6 & $\begin{array}{l}1.7 \cdot 06 \\
2.7 \cdot 05\end{array}$ & $7 \cdot 05$ & & $6 \cdot 59$ & $+0 \cdot 46$ & 0.077 \\
\hline
\end{tabular}

12 NOON TO 3 P.M.

\begin{tabular}{|c|c|c|c|c|c|c|}
\hline & & Initial & content- & $\begin{array}{r}1.6 \cdot 46 \\
-2.6 \cdot 48\end{array}$ & $\{6 \cdot 47$ & \\
\hline 0 & $\begin{array}{l}1.7 \cdot 44 \\
2.7 \cdot 00\end{array}$ & $7 \cdot 22 *$ & $1.6 \cdot 34$ & $6 \cdot 36$ & $+0 \cdot 86$ & $0 \cdot 143$ \\
\hline$\frac{1}{2}$ & $1.8 \cdot 00^{\circ}$ & $8 \cdot 00$ & $1.6 \cdot 34$ & $6 \cdot 36$ & $+1 \cdot 64$ & $0 \cdot 273$ \\
\hline 1 & $\left.\begin{array}{l}1.7 \cdot 97 \\
2.7 \cdot 98\end{array}\right\}$ & $\{7 \cdot 97$ & $1.6 \cdot 33$ & $6 \cdot 36$ & $+1 \cdot 61$ & $0 \cdot 268$ \\
\hline 2 & $\begin{array}{l}1.7 \cdot 83 \\
2.7 \cdot 87\end{array}$ & $7 \cdot 85$ & $1.6 \cdot 40$ & $6 \cdot 36$ & $+1 \cdot 49$ & $0 \cdot 248$ \\
\hline 4 & $\left.\begin{array}{l}1.7 \cdot 27 \\
2.7 \cdot 28\end{array}\right\}$ & $\{7 \cdot 27$ & $1.6 \cdot 35$ & $6 \cdot 36$ & +0.91 & $0 \cdot 151$ \\
\hline & $\left.\begin{array}{l}1.6 \cdot 87 \\
2.6 \cdot 86\end{array}\right\}$ & 6.87 & $1.6 \cdot 42$ & $6 \cdot 36$ & +0.51 & 0.085 \\
\hline
\end{tabular}

3 P.M. Tо 6 P.M.

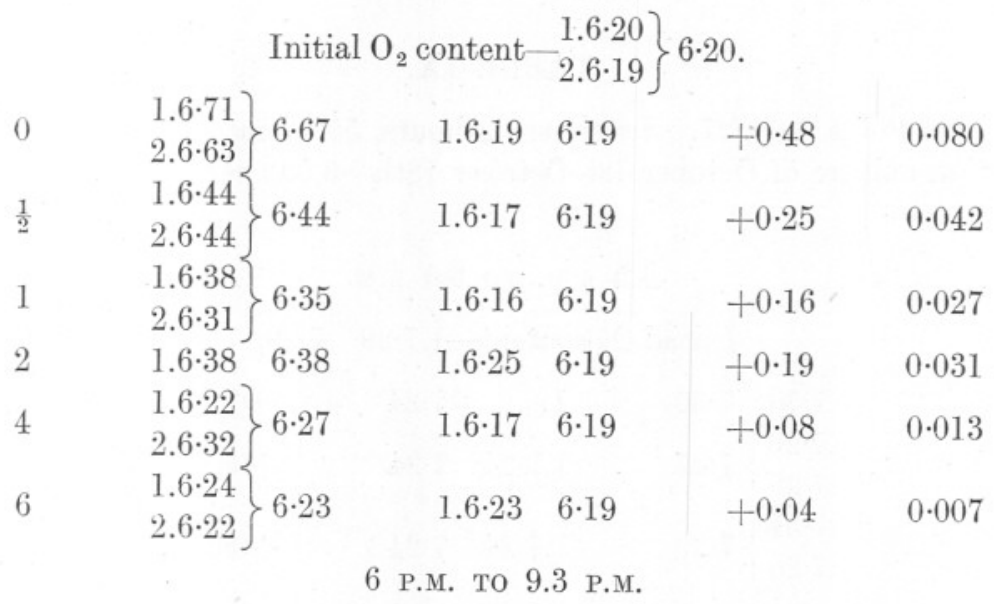

Initial $\mathrm{O}_{2}$ content- $\left.\begin{array}{r}1.6 \cdot 07 \\ 2.6 \cdot 06\end{array}\right\} 6 \cdot 06$.

\begin{tabular}{|c|c|c|c|}
\hline 0 & $1.6 \cdot 03 \quad 6 \cdot 03$ & $1.6 \cdot 02$ & $6 \cdot 02$ \\
\hline 1 & $\left.\begin{array}{l}1.6 \cdot 03 \\
2.6 \cdot 04\end{array}\right\} 6 \cdot 04$ & $1.6 \cdot 05$ & $6 \cdot 02$ \\
\hline
\end{tabular}

* It is probable that these bottles have been interchanged, which would make the readings $7 \cdot 22$ and $7 \cdot 21$.

NEW SERIEs. - Vol. XV. No. 1. FEBRUAlt, 1928. 


\begin{tabular}{|c|c|c|c|c|c|}
\hline $\begin{array}{l}\text { Depth in } \\
\text { metres. }\end{array}$ & Light. & $\mathrm{Da}$ & & $\begin{array}{l}\text { Total } \mathrm{O}_{2} \\
\text { produced. }\end{array}$ & $\begin{array}{c}\mathrm{O}_{2} \text { produced } \\
\text { by } 10^{6} \\
\text { diatoms. }\end{array}$ \\
\hline 1 & $\left.\begin{array}{l}1.6 \cdot 02 \\
2.5 \cdot 96\end{array}\right\} 5 \cdot 99$ & $1.5 \cdot 97$ & $6 \cdot 02$ & - & \\
\hline 2 & $\left.\begin{array}{l}1.6 \cdot 02 \\
2.6 \cdot 07\end{array}\right\} 6 \cdot 05$ & $1.6 \cdot 05$ & $6 \cdot 02$ & +0.03 & \\
\hline 4 & $\left.\begin{array}{l}1.6 \cdot 04 \\
2.6 \cdot 05\end{array}\right\} 6 \cdot 04$ & & 6.02 & +0.02 & \\
\hline 6 & $\left.\begin{array}{l}1.6 \cdot 05 \\
\therefore .6 \cdot 02\end{array}\right\} 6 \cdot 04$ & $1.6 \cdot 01$ & $6 \cdot 02$ & +0.02 & \\
\hline
\end{tabular}

Composite Curve.

$\begin{array}{ccc} & \begin{array}{c}\text { Total } \mathrm{O}_{2} \\ \text { produced. }\end{array} & \begin{array}{c}\mathrm{O}_{2} \text { produced by } \\ 10^{6} \text { diatoms. }\end{array} \\ \text { Surface } & +3 \cdot 17 & 0.528 \\ \frac{1}{2} \mathrm{~m} . & +3 \cdot 42 & 0.570 \\ 1 \mathrm{~m} . & +3 \cdot 35 & 0.558 \\ 2 \mathrm{~m} . & +3.17 & 0.533 \\ 4 \mathrm{~m} . & +1.98 & 0.330 \\ 6 \mathrm{~m} . & +1.05 & 0 \cdot 175\end{array}$

\section{TABLE IX.}

Farland Point, 9/11/27. Sunshine -2 hours, 55 minutes.

Diatom culture of October 1st-October 18 th $-5,600$ cells per c.c.

3.5 А.м. то 6.0 А.м.

Initial $\mathrm{O}_{2}$ content- $1.7 \cdot 29 \quad 7 \cdot 29$.

\begin{tabular}{|c|c|c|c|c|c|c|}
\hline 0 & $1.7 \cdot 30$ & $7 \cdot 30$ & 1. & $7 \cdot 24$ & $+0 \cdot 06$ & 0.011 \\
\hline$\frac{1}{2}$ & $\begin{array}{l}1.7 \cdot 26 \\
2.7 \cdot 29\end{array}$ & $7 \cdot 27$ & $1.7 \cdot 24$ & $7 \cdot 24$ & +0.03 & - \\
\hline 1 & $\begin{array}{l}1.7 \cdot 31 \\
2.7 \cdot 26\end{array}$ & $7 \cdot 29$ & $1.7 \cdot 24$ & $7 \cdot 24$ & +0.05 & \\
\hline 2 & $\begin{array}{l}1.7 \cdot 21 \\
2.7 \cdot 19\end{array}$ & $7 \cdot 20$ & $1.7 \cdot 24$ & $7 \cdot 24$ & - & \\
\hline 4 & $\begin{array}{l}1.7 \cdot 24 \\
2.7 \cdot 26\end{array}$ & $7 \cdot 25$ & $1.7 \cdot 23$ & $7 \cdot 24$ & +0.01 & \\
\hline & $\begin{array}{l}1.7 \cdot 26 \\
2.7 \cdot 22\end{array}$ & $7 \cdot 24$ & $1.7 \cdot 25$ & $7 \cdot 24$ & - & \\
\hline
\end{tabular}


6.5 А.м. то 9.0 A.M.

Initial $\mathrm{O}_{2}$ content- $\left.\begin{array}{r}1.6 \cdot 70 \\ 2.6 \cdot 61\end{array}\right\} 6 \cdot 65$.

\begin{tabular}{|c|c|c|c|c|c|c|}
\hline 0 & $1.7 \cdot 27$ & $7 \cdot 27$ & $1.6 \cdot 74$ & $6 \cdot 73$ & +0.54 & 0.096 \\
\hline & $\begin{array}{l}1.7 \cdot 15 \\
2.7 \cdot 15\end{array}$ & $7 \cdot 15$ & $1.6 \cdot 72$ & $6 \cdot 73$ & $+0 \cdot 42$ & 0.075 \\
\hline & $\begin{array}{l}1.7 \cdot 10 \\
2.7 \cdot 08\end{array}$ & $7 \cdot 09$ & $1.6 \cdot 72$ & $6 \cdot 73$ & $+0 \cdot 36$ & 0.064 \\
\hline & $\begin{array}{l}1.6 \cdot 97 \\
2.7 .00\end{array}$ & $6 \cdot 98$ & $1.6 \cdot 70$ & $6 \cdot 73$ & $+0 \cdot 25$ & $0 \cdot 045$ \\
\hline & $\begin{array}{l}1.6 \cdot 84 \\
2.6 \cdot 86\end{array}$ & $6 \cdot 85$ & $1.6 \cdot 71$ & $6 \cdot 73$ & $+0 \cdot 12$ & 0.021 \\
\hline & $\left.\begin{array}{l}1.6 \cdot 81 \\
2.6 \cdot 82\end{array}\right\}$ & $6 \cdot 81$ & $1.6 \cdot 76$ & $6 \cdot 73$ & +0.08 & $0 \cdot 014$ \\
\hline & & Initis & м. то & $\begin{array}{r}2 \text { Noo } \\
1.6 .57 \\
2.6 .48\end{array}$ & 33. & \\
\hline 0 & $1.8 \cdot 11$ & $8 \cdot 11$ & 1.6 .55 & $6 \cdot 55$ & $+1 \cdot 56$ & $0 \cdot 279$ \\
\hline & $\begin{array}{l}1.8 \cdot 12 \\
2.8 \cdot 18\end{array}$ & $8 \cdot 15$ & 1.6 .52 & 6.55 & $+1 \cdot 60$ & $0 \cdot 286$ \\
\hline 1 & $\begin{array}{l}1.8 \cdot 12 \\
2.8 \cdot 11\end{array}$ & $8 \cdot 11$ & $1.6 \cdot 57$ & $6 \cdot 55$ & $+1 \cdot 56$ & $0 \cdot 279$ \\
\hline & $\begin{array}{l}1.7 \cdot 79 \\
2.7 \cdot 84\end{array}$ & $7 \cdot 81$ & 1.6 .57 & 6.55 & $+1 \cdot 26$ & $0 \cdot 225$ \\
\hline & $\begin{array}{l}1.7 \cdot 23 \\
2.7 \cdot 18\end{array}$ & $7 \cdot 20$ & 1.6 .56 & $6 \cdot 55$ & +0.65 & $0 \cdot 116$ \\
\hline & $1.6 \cdot 90$ & $6 \cdot 90$ & 1.6 .55 & $6 \cdot 55$ & +0.35 & $0 \cdot 063$ \\
\hline
\end{tabular}

12 NOON TO 3 P.M.

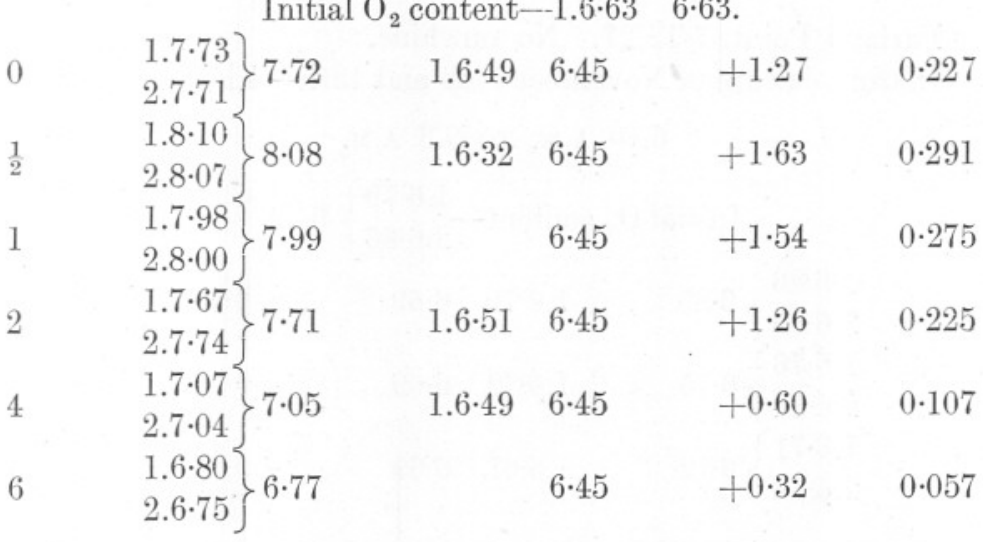


3.10 P.м. то 6.0 Р.м.

\begin{tabular}{|c|c|c|c|c|c|c|}
\hline & & Initi & ontent- & $\begin{array}{r}1.6 \cdot 22 \\
2.6 \cdot 18\end{array}$ & 20. & \\
\hline $\begin{array}{l}\text { Depth in } \\
\text { metres. }\end{array}$ & Light. & & Dar & & $\begin{array}{l}\text { Total } \mathrm{O}_{2} \\
\text { produced. }\end{array}$ & $\begin{array}{l}\text { by } 10^{6} \\
\text { diatoms. }\end{array}$ \\
\hline 0 & $\left.\begin{array}{l}1.6 \cdot 54 \\
2.6 \cdot 52\end{array}\right\}$ & $6 \cdot 52$ & $1.6 \cdot 17$ & $6 \cdot 18$ & $+0 \cdot 34$ & $0 \cdot 061$ \\
\hline$\frac{1}{2}$ & $\left.\begin{array}{l}1.6 \cdot 53 \\
2.6 \cdot 51\end{array}\right\}$ & $6 \cdot 52$ & $1.6 \cdot 20$ & $6 \cdot 18$ & $+0 \cdot 34$ & $0 \cdot 061$ \\
\hline 1 & $\left.\begin{array}{l}1.6 \cdot 36 \\
2.6 \cdot 34\end{array}\right\}$ & $6 \cdot 35$ & $1.6 \cdot 17$ & $6 \cdot 18$ & $+0 \cdot 17$ & $0 \cdot 030$ \\
\hline 2 & $\left.\begin{array}{l}1.6 \cdot 32 \\
2.6 \cdot 33\end{array}\right\}$ & $6 \cdot 33$ & $1.6 \cdot 20$ & $6 \cdot 18$ & $+0 \cdot 15$ & $0 \cdot 027$ \\
\hline 4 & $\left.\begin{array}{l}1.6 \cdot 26 \\
2.6 \cdot 26\end{array}\right\}$ & $6 \cdot 26$ & $1.6 \cdot 17$ & $6 \cdot 18$ & $+0 \cdot 08$ & $0 \cdot 014$ \\
\hline 6 & $1.6 \cdot 08$ & $6 \cdot 08$ & 1. & $6 \cdot 18$ & - & - \\
\hline
\end{tabular}

\section{Composite Curve.}

$\begin{array}{crc} & \begin{array}{c}\text { Total } \mathrm{O}_{2} \\ \text { produced. }\end{array} & \begin{array}{c}\mathrm{O}_{2} \text { produced by } \\ 10^{6} \text { diatoms. }\end{array} \\ \text { Surface } & +3 \cdot 80 & 0 \cdot 679 \\ \frac{1}{2} \mathrm{~m} . & +4 \cdot 05 & 0 \cdot 723 \\ 1 \mathrm{~m} . & +3 \cdot 68 & 0 \cdot 657 \\ 2 \mathrm{~m} . & +2.92 & 0 \cdot 521 \\ 4 \mathrm{~m} . & +1 \cdot 46 & 0 \cdot 261 \\ 6 \mathrm{~m} . & +0.75 & 0 \cdot 134\end{array}$

\section{TABLE X.}

Farland Point, $7 / 12 / 27$. No sunshine.

Diatom culture of November 11th and 13th-4,100 cells per c.c.

$$
6.10 \text { А.м. то } 9.3 \text { A.м. }
$$

\begin{tabular}{|c|c|c|c|c|c|c|}
\hline & & Initis & ontent- & $\begin{array}{r}1.6 \cdot 7 \\
-2.6 \cdot 6\end{array}$ & 72. & \\
\hline 0 & $\left.\begin{array}{l}1.6 \cdot 86 \\
2.6 \cdot 83\end{array}\right\}$ & $6 \cdot 85$ & $1.6 \cdot 79$ & $6 \cdot 69$ & $+0 \cdot 16$ & $0 \cdot 039$ \\
\hline$\frac{1}{8}$ & $\left.\begin{array}{l}1.6 \cdot 76 \\
2.6 \cdot 74\end{array}\right\}$ & 6.75 & $1.6 \cdot 72$ & $6 \cdot 69$ & $+0 \cdot 06$ & $0 \cdot 015$ \\
\hline 1 & $\begin{array}{l}1.6 \cdot 71 \\
2.6 \cdot 73\end{array}$ & $6 \cdot 72$ & $1.6 \cdot 67$ & $6 \cdot 69$ & +0.03 & $0 \cdot 007$ \\
\hline
\end{tabular}




$\left.\begin{array}{lll}2 & \begin{array}{l}1.6 \cdot 66 \\ 2.6 \cdot 72\end{array} \\ 4 & \begin{array}{l}1.6 \cdot 69 \\ 2.6 \cdot 69\end{array} \\ 4 & \begin{array}{l}1.6 \cdot 69 \\ 6\end{array} \\ 6 & 2.6 \cdot 69\end{array}\right\} \begin{array}{llll}6 \cdot 69 & 1.6 \cdot 68 & 6 \cdot 69 \\ 6 \cdot 68 & & 1.6 \cdot 63 & 6 \cdot 69\end{array}$

9.7 А.м. то 12.4 P.м.

Initial $\mathrm{O}_{2}$ content- $\left.\begin{array}{r}1.6 \cdot 00 \\ 2.5 \cdot 91\end{array}\right\} 5 \cdot 95$.

\begin{tabular}{|c|c|c|c|c|}
\hline $\begin{array}{l}1.6 \cdot 63 \\
2.6 \cdot 62\end{array}$ & $6 \cdot 63$ & $1.5 \cdot 95$ & $5 \cdot 94$ & $+0.69^{\circ}$ \\
\hline $\begin{array}{l}1.6 .51 \\
2.6 .53\end{array}$ & $6 \cdot 52$ & $1.5 \cdot 95$ & $5 \cdot 94$ & +0.58 \\
\hline $\begin{array}{l}1.6 .51 \\
2.6 .53\end{array}$ & $6 \cdot 40$ & $1.5 \cdot 93$ & $5 \cdot 94$ & $+0 \cdot 46$ \\
\hline $\begin{array}{l}1.6 \cdot 28 \\
2.6 \cdot 29\end{array}$ & $6 \cdot 28$ & $1.5 \cdot 98$ & $5 \cdot 94$ & $+0 \cdot 34$ \\
\hline $\begin{array}{l}1.6 \cdot 14 \\
2.6 \cdot 16\end{array}$ & $6 \cdot 15$ & $1.5 \cdot 88$ & $5 \cdot 94$ & $+0 \cdot 21$ \\
\hline $\begin{array}{l}1.6 \cdot 04 \\
2.6 \cdot 05\end{array}$ & $6 \cdot 05$ & $1.5 \cdot 99$ & $5 \cdot 94$ & $+0 \cdot 11$ \\
\hline
\end{tabular}

12.4 P.M. то 3 P.M.

Initial $\mathrm{O}_{2}$ content- $\left.\begin{array}{r}1.5 \cdot 96 \\ 2.5 \cdot 91\end{array}\right\} 5 \cdot 93$.

\begin{tabular}{|c|c|c|c|c|c|}
\hline $\begin{array}{l}1.6 \cdot 72 \\
2.6 \cdot 72\end{array}$ & $6 \cdot 72$ & $1.5 \cdot 92$ & $5 \cdot 91$ & +0.81 & $0 \cdot 198$ \\
\hline $\begin{array}{l}1.6 \cdot 47 \\
2.6 \cdot 46\end{array}$ & $6 \cdot 46$ & $1.5 \cdot 93$ & $5 \cdot 91$ & +0.55 & $0 \cdot 134$ \\
\hline $\begin{array}{l}1.6 \cdot 31 \\
2.6 \cdot 33\end{array}$ & $6 \cdot 32$ & $1.5 \cdot 91$ & $5 \cdot 91$ & $+0 \cdot 41$ & $0 \cdot 100$ \\
\hline $\begin{array}{l}1.6 \cdot 20 \\
2.6 \cdot 26\end{array}$ & $6 \cdot 23$ & $1.5 \cdot 91$ & $5 \cdot 91$ & +0.32 & 0.078 \\
\hline $\begin{array}{l}1.6 \cdot 12 \\
2.6 \cdot 08\end{array}$ & $6 \cdot 10$ & $1.5 \cdot 91$ & $5 \cdot 91$ & $+0 \cdot 19$ & 0.046 \\
\hline $\begin{array}{l}1.6 \cdot 02 \\
2.6 \cdot 03\end{array}$ & $6 \cdot 03$ & $1.5 \cdot 91$ & $5 \cdot 91$ & $+0 \cdot 12$ & 0.029 \\
\hline
\end{tabular}




\section{P.M. Tо 6 P.м.}

Initial $\mathrm{O}_{2}$ content- $\left.\begin{array}{r}1.5 \cdot 85 \\ 2.5 \cdot 79\end{array}\right\} 5 \cdot 82$.

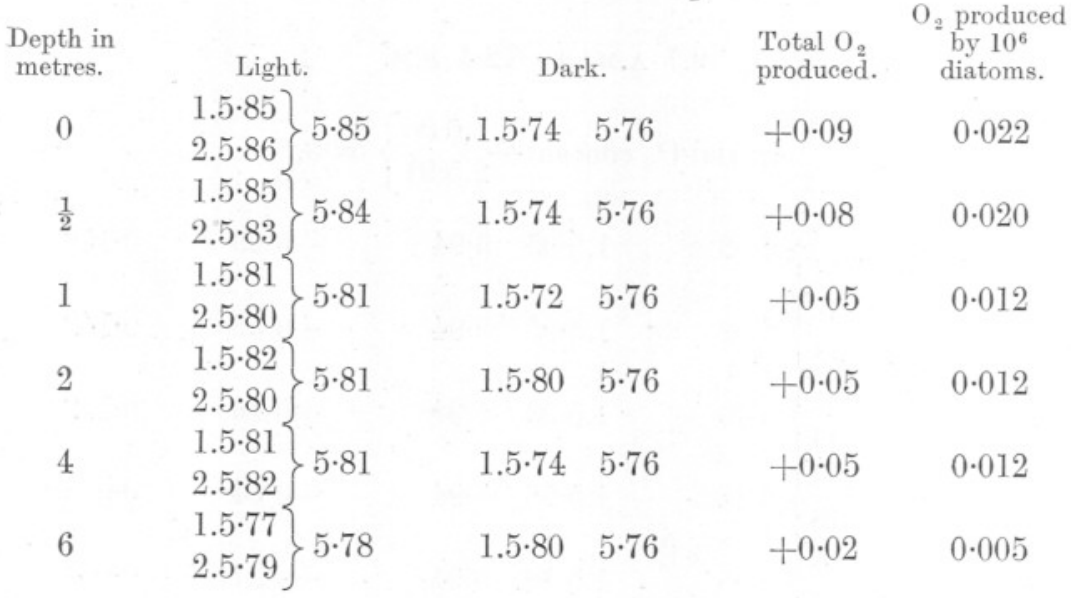

Composite Curve.

$\begin{array}{ccc} & \begin{array}{c}\text { Total } \mathrm{O}_{2} \\ \text { produced. }\end{array} & \begin{array}{c}\mathrm{O}_{2} \text { produced by } \\ 10^{6} \text { diatoms. }\end{array} \\ \text { Surface } & +1.75 & 0 \cdot 427 \\ \frac{1}{2} \mathrm{~m} . & +1.27 & 0.310 \\ 1 \mathrm{~m} . & +0.95 & 0 \cdot 232 \\ 2 \mathrm{~m} . & +0 \cdot 71 & 0 \cdot 173 \\ 4 \mathrm{~m} . & +0.45 & 0 \cdot 110 \\ 6 \mathrm{~m} . & +0.25 & 0.061\end{array}$




\section{TABLE XI.}

Loch Striven, 27-28/5/27. Sunshine-11 hours 10 minutes.

Culture of Coscinosira, May 4th and 10th-3,700 cells per c.c.

Culture of Chætoceros May 2nd, 13,900 cells per c.c.

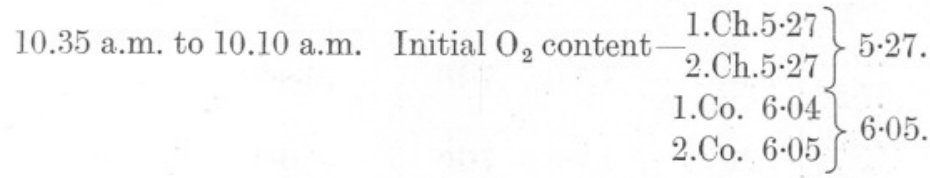

\begin{tabular}{|c|c|c|c|c|c|c|c|c|}
\hline & Light & & Dark. & & $\begin{array}{l}\text { Tot } \\
\text { proc }\end{array}$ & $\begin{array}{l}\mathrm{ll}_{2} \\
\text { uced. }\end{array}$ & $\begin{array}{c}\mathrm{O}_{2} \text { produced } \\
\text { by } 10^{6} \\
\text { diatoms. }\end{array}$ & $\begin{array}{l}\text { Temp- } \\
\text { erature. }\end{array}$ \\
\hline & 1.Ch. $4 \cdot 41$ & $4 \cdot 41$ & 1.Ch.5.05 & $4 \cdot 66$ & Ch. & Co. & Ch. Co. & ${ }^{\circ} \mathrm{C}$. \\
\hline 0 & 2.Co. $7 \cdot 69$ & $7 \cdot 69$ & 2.Co. $5 \cdot 33$ & $5 \cdot 36$ & & & $-0 \cdot 018+0 \cdot 63$ & $10 \cdot 62$ \\
\hline$\frac{1}{2}$ & 1.Ch. $6 \cdot 99$ & $7 \cdot 01$ & 1.Ch. $4 \cdot 60$ & $4 \cdot 66$ & -2 & +4 & $69+1 \cdot$ & \\
\hline 2 & $\begin{array}{l}\text { 2.Ch. } 7 \cdot 02 \\
\text { 3.Co. } 9 \cdot 95\end{array}$ & $9 \cdot 95$ & 2.Co.5.21 & $5 \cdot 36$ & & & $09+1$. & \\
\hline 1 & 1.Ch. $7 \cdot 64$ & $7 \cdot 64$ & 1.Ch. $4 \cdot 58$ & $4 \cdot 66$ & & & & \\
\hline & 2. Co. $10 \cdot 70$ & $10 \cdot 70$ & 2.Co.5 $\cdot 34$ & $5 \cdot 36$ & $+2 \cdot 98$ & $+5 \cdot 3$ & $+0 \cdot 214+1$ & \\
\hline 2 & 1.Ch. $7 \cdot 52$ & $7 \cdot 52$ & 1.Ch. $4 \cdot 66$ & $4 \cdot 66$ & $+2 \cdot 86$ & +4.08 & $+0 \cdot 206+1 \cdot 10$ & $10 \cdot 59$ \\
\hline & $\begin{array}{l}\text { 2.Co. } 9 \cdot 47 \\
\text { 3.Co. } 9 \cdot 42\end{array}$ & $9 \cdot 44$ & 2.Co.5 $\cdot 37$ & $5 \cdot 36$ & & & & $(2 \cdot 5$ \\
\hline 3 & 1.Ch. $7 \cdot 55$ & $7 \cdot 54$ & 1.Ch. $4 \cdot 73$ & $4 \cdot 66$ & $+2 \cdot 88$ & $+4 \cdot 24$ & & \\
\hline & 2.Ch. 7.52 & & 2.Co.5·34 & $5 \cdot 36$ & & & & \\
\hline & 1.Ch. $7 \cdot 46$ & $7 \cdot 46$ & 1.Ch. $4 \cdot 6$ & $4 \cdot 66$ & & & & \\
\hline 4 & 2.Co. $8 \cdot 79$ & $8 \cdot 79$ & Co. & $5 \cdot 36$ & $+2 \cdot 80$ & $+3 \cdot 43$ & $+0 \cdot 201+0 \cdot 93$ & \\
\hline 5 & 1.Ch. $7 \cdot 22$ & $7 \cdot 22$ & 1.Ch.4.71 & $4 \cdot 66$ & & & & \\
\hline & $\begin{array}{l}\text { 2.Co. } 7 \cdot 77 \\
\text { 3.Co. } 8 \cdot 08\end{array}$ & $7 \cdot 92$ & 2.Co.5.50 & $5 \cdot 36$ & & & & $10 \cdot j 2$ \\
\hline 6 & 1.Ch. $6 \cdot 88$ & $6 \cdot 88$ & 1.Ch. $4 \cdot 65$ & $4 \cdot 66$ & +2.29 & $+2 \cdot 1$ & & \\
\hline & 2.Co. $7 \cdot 52$ & $7 \cdot 52$ & 2.Co.5.40 & $5 \cdot 36$ & & & & \\
\hline 7 & 1.Ch. $6 \cdot 49$ & $6 \cdot 49$ & 1.Ch. $4 \cdot 68$ & $4 \cdot 66$ & $+1 \cdot 83$ & $+2 \cdot 02$ & $+0 \cdot 132+0.55$ & 91 \\
\hline & 2.Co. $7 \cdot 39$ & $7 \cdot 39$ & Co. & $5 \cdot 36$ & & & & 971 \\
\hline
\end{tabular}




\section{TABLE XII.}

Off Hunterston Perch, 18/7/27. 10.50 a.m.-3.50 p.m. All sunshine. Water sample contained about 200 chains per c.c., mostly Skeletonema,

Thalassiosira, and Chætoceros. Average number of cells per chain, 5 .

\begin{tabular}{|c|c|c|c|c|c|c|}
\hline \multirow{3}{*}{$\begin{array}{c}\text { Depth in } \\
\text { metres. } \\
0\end{array}$} & & Initis & content- & $\begin{array}{l}1.7 \cdot 09 \\
-2.7 \cdot 07 \\
3.7 \cdot 08\end{array}$ & $7 \cdot 08$ & \multirow{2}{*}{$\begin{array}{c}\mathrm{O}_{2} \text { produced } \\
\text { by } 10^{6} \\
\text { diatoms. }\end{array}$} \\
\hline & \multicolumn{2}{|c|}{ Light. } & \multicolumn{2}{|c|}{ Dark. } & $\begin{array}{l}\text { Total } \mathrm{O}_{2} \\
\text { produced. }\end{array}$ & \\
\hline & $\begin{array}{l}1.7 \cdot 31 \\
2.7 \cdot 25\end{array}$ & $7 \cdot 28$ & $1.7 \cdot 08$ & $7 \cdot 10$ & $+0 \cdot 18$ & $0 \cdot 18$ \\
\hline$\frac{1}{2}$ & $\begin{array}{l}1.7 \cdot 49 \\
2.7 \cdot 49\end{array}$ & $7 \cdot 49$ & $1.7 \cdot 08$ & $7 \cdot 10$ & $+0 \cdot 39$ & $0 \cdot 39$ \\
\hline 1 & $\begin{array}{l}1.7 \cdot 51 \\
2.7 \cdot 54\end{array}$ & $7 \cdot 53$ & $1.7 \cdot 10$ & $7 \cdot 10$ & $+0 \cdot 43$ & $0 \cdot 43$ \\
\hline 2 & $\begin{array}{l}1.7 \cdot 53 \\
2.7 \cdot 53\end{array}$ & $7 \cdot 53$ & $1.7 \cdot 09$ & $7 \cdot 10$ & $+0 \cdot 43$ & $0 \cdot 43$ \\
\hline 4. & $\begin{array}{l}1.7 \cdot 45 \\
2.7 \cdot 44\end{array}$ & $7 \cdot 44$ & $1.7 \cdot 04$ & $7 \cdot 10$ & $+0 \cdot 34$ & $0 \cdot 34$ \\
\hline 6 & $\begin{array}{l}1.7 \cdot 30 \\
2.7 \cdot 33\end{array}$ & $7 \cdot 31$ & $1.7 \cdot 11$ & $7 \cdot 10$ & $+0 \cdot 21$ & $0 \cdot 21$ \\
\hline 8 & $\begin{array}{l}1.7 \cdot 26 \\
2.7 \cdot 26\end{array}$ & $7 \cdot 26$ & $1.7 \cdot 12$ & $7 \cdot 10$ & $+0 \cdot 16$ & $0 \cdot 16$ \\
\hline 10 & $\begin{array}{l}1.7 \cdot 21 \\
2.7 \cdot 16\end{array}$ & $7 \cdot 18$ & $1.7 \cdot 12$ & $7 \cdot 10$ & $+0 \cdot 08$ & $0 \cdot 08$ \\
\hline 12 & $\begin{array}{l}1.7 \cdot 18 \\
2.7 \cdot 20\end{array}$ & $7 \cdot 19$ & $1.7 \cdot 10$ & $7 \cdot 10$ & +0.09 & $0 \cdot 09$ \\
\hline 15 & $\begin{array}{l}1.7 \cdot 15 \\
2.7 \cdot 13\end{array}$ & $7 \cdot 14$ & $1.7 \cdot 15$ & $7 \cdot 10$ & $+0 \cdot 04$ & $0 \cdot 04$ \\
\hline
\end{tabular}

\section{TABLE XIII.}

Light Intensity.

mg. Oxalic Acid decomposed.

Time.

12 midnight-3 a.m.

3 a.m. -6 a.m.

6 a.m. -9 a.m.

9 a.m. -12 noon

12 noon-3 p.m.

3 p.m. -6 p.m.

6 p.m. -9 p.m.

9 p.m.-12 midnight
9-10/6/27. 28/6/27. 29/11/27.

$\begin{array}{rcccc}1 \cdot 0 & 0 & 0 & 0 & 0 \\ 77 \cdot 2 & 10 \cdot 7 & 0 & 0 & 0 \\ 191 \cdot 7 & 97 \cdot 8 & 8 \cdot 5 & 11 \cdot 8 & 0 \cdot 7 \\ 333 \cdot 4 & 119 \cdot 8 & 113 \cdot 0 & 89 \cdot 2 & 12 \cdot 5 \\ 390 \cdot 4 & 94 \cdot 7 & 123 \cdot 6 & 102 \cdot 0 & 10 \cdot 4 \\ 285 \cdot 3 & 39 \cdot 9 & 4 \cdot 5 & 2 \cdot 6 & 1 \cdot 0 \\ 70 \cdot 0 & 12 \cdot 0 & 0 & 0 & 0 \\ 0 \cdot 5 & 0 \cdot 7 & 0 & 0 & 0\end{array}$

